\title{
Remittances and the Wage Impact of Immigration
}

\author{
William W. Olney ${ }^{1}$
}

First Draft: November 2011

Revised: April 2014

\begin{abstract}
This paper examines how the outflow of remittances affect the wages of native workers. The model shows that the wage impact of immigration depends on the competing effects of an increase in labor market competition and an increase in the consumer base. Immigrant remittances provide a unique way of isolating this latter effect since they reduce the consumer base but not the workforce. The predictions of the model are tested using an unusually rich German data set that has detailed information on remittances and wages. As expected, the results indicate that a one percent increase in remittances depress the wages of native workers by $0.06 \%$. Furthermore, remittances predominantly affect workers in non-traded industries that are more reliant on domestic consumption.

Keywords: Remittances, Immigration, Wages

JEL Codes: J61, F24, J31

\footnotetext{
${ }^{1}$ Department of Economics, Williams College, Williamstown, MA $01267 \quad$ (email: william.olney@williams.edu). I am grateful to George Borjas, David Card, Dan Hickman, Chad Sparber and seminar participants at UC Berkeley, UC Santa Barbara, Pomona, the Canadian Economics Association (HEC Montreal), Wesleyan, Colgate, the Economic Development International Conference (U Bordeaux), the Midwest International Trade Meetings (Vanderbilt U), and Williams for helpful comments and suggestions.
} 


\section{Introduction}

Critics of immigration tend to be concerned that foreign migrants will take the jobs or depress the wages of native workers. As a result, the immigration debate often focuses on the impact that immigrants have on the wages and employment of similarly skilled native workers. However, immigrants also demand goods and services which can alleviate this adverse labor competing effect. Although intuitively appealing, little work has examined the impact of immigration on the consumer base. In order to clarify these competing effects, this paper presents a simple model that identifies how immigration can affect wages through an increase in labor market competition and an increase in product demand. The predictions of this model are then tested using a German data set that has detailed information on immigrant and native workers.

Unfortunately, due to a lack of data it is hard to empirically measure an immigrantinduced change in the consumer base. However, immigrant remittances provide a unique opportunity to identify changes in domestic consumption. As immigrants send more money home in the form of remittances, they have less to spend domestically, and thus the consumer base will shrink. Therefore, focusing on remittances is a useful way of separately identifying the wage impact of immigrant consumption from the labor competing effects of immigration.

Remittances have increased steadily over the past decade and were valued at $\$ 416$ billion in $2009 .^{2}$ Remittance flows into developing countries are large (they exceed official aid and are close to foreign direct investment inflows) and the benefits to these recipient countries are well documented. ${ }^{3}$ Given the positive implications for receiving countries, it is reasonable to expect a more adverse impact on developed countries that typically send remittances abroad. This is a trade-off many would be willing to make and thus this paper should not be viewed as a critique of remittances. However, little is actually known about how the outflow of remittances affects these developed countries. Thus, another goal of this analysis is to provide the first careful assessment of how remittances affect the sending country's economy.

The model shows that immigration affects wages through labor market competition

\footnotetext{
${ }^{2}$ World Bank Migration and Remittances Factbook 2011.

${ }^{3}$ See Yang (2011) for a survey of the literature and a comparison of remittances, FDI, and official aid.
} 
and through changes in the consumer base. Immigrant remittances lead to changes in the consumer base but not the workforce. Thus, the first prediction of the model is that as remittances increase the domestic consumer base shrinks and native wages will decline. The second prediction is that remittances will have a more negative impact on the wages of native workers in non-traded industries since these industries depend more heavily on local consumption. The wages of workers in traded industries are less affected because changes in the local consumer base have a relatively small impact on the overall demand for these goods.

The predictions of the model are tested using data from the German Socio-Economic Panel Study (SOEP) which is appealing for a couple reasons. First, Germany is one of the most important migrant host countries and remittance source countries. For instance, there were 10.7 million immigrants in Germany in 2010, the third highest amount in the world, and the outflow of remittances from Germany in 2009 totaled $\$ 15.9$ billion, which was fifth most in the world. ${ }^{4}$ Second, the German SOEP data is unusual in that it has detailed information on remittances, income, location, and demographic characteristics of natives and immigrants from 1984 to 2008. Thus, this data set provides a unique opportunity to test the predictions of the model and examine the impact of remittances on native wages.

The empirical specification essentially estimates how changes in the total amount of remittances leaving a German state affect the wages of individual native workers within that state after controlling for immigration, demographic characteristics, state fixed effects, year fixed effects, and industry fixed effects. One potential concern is that an income shock within a particular state could lead to higher native wages and lead to wealthier immigrants remitting more money abroad. Although this would, if anything, work against finding a significant negative result, an IV analysis is also used in order to address these potential endogeneity concerns and identify the causal impact of remittances on wages. The instrument is constructed using variation in remittances that is driven by factors in the foreign country which are exogenous to local economic conditions in Germany.

The results confirm the first prediction of the model. Even the OLS results, which likely suffer from a spurious positive endogeneity bias, indicate that remittances decrease

\footnotetext{
${ }^{4}$ World Bank Migration and Remittances Factbook 2011.
} 
native wages. As expected, the IV results are more negative and indicate that a one percent increase in remittances leads to a $0.06 \%$ reduction in the wages of native workers within that state. As the consumer base shrinks, native wages decline.

Consistent with the second prediction of the model, the impact of remittances also varies across different types of industries. Specifically, the results show that the negative impact of remittances predominantly affect workers employed in non-traded industries which are more reliant on domestic consumption. Furthermore, using a separate data set on industry valueadded, an additional set of results show that remittances primarily decrease the output of non-traded industries. This confirms the prediction of the model that the observed relationship between remittances and wages is driven by changes in the consumer base.

A number of other extensions support these baseline results. First, results show that remittances have a more negative impact on the wages of workers in non-unionized industries. Unionized industries have more rigid wage structures and are thus less affected by fluctuations in remittances. Second, in contrast to remittances to friends and family, remittances motivated by the desire to save in the foreign country do not significantly affect native wages. This type of remittances will decrease domestic savings but are unlikely to significantly affect the domestic consumer base or wages. Finally, a variety of additional sensitivity checks indicate that the key results of this paper are robust to using an alternate instrument, including individual fixed effects, using a broader sample, clustering the standard errors at the state level, excluding East-Germans who may have migrated to West-Germany after the fall of the Berlin Wall, and including alternate immigrant controls.

Existing studies tend to focus on the impact that remittances have on developing countries that receive these funds. Typically remittances are found to enhance the economic performance of the receiving country, including increasing household welfare, reducing poverty, increasing education, and insuring against income shocks (The World Bank 2008, Chami et al. 2008, Yang 2008, and Rapoport and Docquier 2006). ${ }^{5}$ Other authors examine the characteristics of those that choose to remit and their motivation for doing so (Lucas and Stark 1985, Funkhouser 1995, de la Briere et al. 2002, Osili 2007, Dustmann and Mestres 2010, Yang 2011). However, relatively little is known about how the outflow of remittances affect

\footnotetext{
${ }^{5}$ Remittances are not always beneficial for the receiving country (see Ahmed 2012).
} 
the economic performance of the remittance-sending country. To the best of my knowledge, this is the first paper to specifically examine the implications of remittances on any aspect of the sending country's economy.

While there is limited research on the impact of remittances on developed countries, there is a large body of work examining whether immigration adversely affects the wages of similarly skilled native workers. The empirical results are mixed, with some studies finding that immigration has a significant negative impact on native wages (Borjas, Freeman, and Katz 1997 and Borjas 2003) while others find a small or insignificant impact (Friedberg and Hunt 1995, Card 2005, Ottaviano and Peri 2012). Although public discourse and previous research often focus on the labor competing effects of immigration, the implications of immigration on the consumer base is also important but seldom studied. Mazzolari and Neumark (2012) and Olney (2013) begin to think more seriously about immigrant consumption by examining the impact of immigration on the number and type of business establishments. However, as far as I know, this is the first paper to examine how an immigrant-induced change in the consumer base affects native wages. ${ }^{6}$

The model presented in this paper is similar to the framework outlined in Borjas (2013), which examines the impact of immigration on wages in a wide variety of more general functional forms. In contrast, this paper makes very simple assumptions about the utility and production functions and yet still generates some useful predictions on how immigration can affect wages through changes in the consumer base and the workforce. The ability to empirically test these predictions using an unusual micro-level German data set represents an important contribution of this paper. The results provide the first direct empirical evidence that immigration can have an significant impact on the consumer base and thus wages.

The remainder of the paper is organized as follows. Section 2 outlines the theoretical framework and the predictions of the model. The empirical specification is discussed in section 3 and the data and descriptive statistics are described in section 4 . The results and

\footnotetext{
${ }^{6}$ A new paper by Hong and McLaren (2013) also focuses on the labor supply and consumer demand effects of immigration. However, Hong and McLaren (2013) are not able to separately identify these competing effects and instead make inferences about their relative size based on the net impact of immigration. As far as I know, this is the first paper to disentangle these competing effects and examine how an immigrant-induced change in the consumer base affects native wages.
} 
extensions are discussed in sections 5 and 6 respectively. Finally, section 7 concludes.

\section{Model}

The goal of this section is to present a simple and intuitive theoretical framework which provides insight into the relationship between remittances and wages. This is accomplished by first identifying how immigration can impact wages through an increase in labor market competition and through an increase in the consumer base. Then the impact of remittances on the consumer base and thus native wages is examined within this context.

\subsection{Immigration}

Following Borjas (2013), the model assumes there are two goods in the economy, with good $q$ produced domestically and good $y$ imported. Complete specialization in production ensures that factor price equalization does not hold and thus there is a motive for immigration. ${ }^{7}$

Assume each consumer $j$ has the following quasilinear utility function:

$$
U(y, q)=y+g_{j}^{*} \frac{q^{\xi}-1}{\xi},
$$

where $\xi<1$ and $g_{j}^{*}$ reflects consumer $j^{\prime} s$ preference for the domestic good. Let $Z$ be the consumer's income and thus the budget constraint is:

$$
Z=y+p q
$$

where $p$ is the price of the domestic good and the price of the imported good is taken as given (because it is determined in the world market) and treated as the numeraire. Maximizing utility subject to the budget constraint generates consumer $j^{\prime} s$ demand function for the domestic good:

\footnotetext{
${ }^{7}$ If there was incomplete specialization, then factor prices would be equalized across countries. In addition, according to the Rybczynski Theorem, immigration would alter the distribution of output without leading to any change in wages.
} 


$$
q_{j}=g_{j} p^{-1 /(1-\xi)}
$$

where $g_{j}$ is a rescaled consumer specific preference. ${ }^{8}$

There are domestic and foreign consumers in this economy. They both have the same quasilinear utility function specified in (1) except that the weighting factor $g$ differs across the two types of consumers. This allows for the possibility that the consumers likely have different preference for the domestically produced good. Let $C_{L}$ be the number of domestic consumers and $C_{X}$ be the number of foreign consumers. Thus, the market demand for the domestic good $(Q)$ is defined as follows:

$$
Q=q_{L} C_{L}+q_{X} C_{X}
$$

which, after substituting in equation (3), becomes

$$
Q=C p^{-1 /(1-\xi)}
$$

where $C=g_{L} C_{L}+g_{X} C_{X}$ is the weighted number of consumers.

This model provides a useful framework in which to think about how immigration affects product demand, which is often overlooked by existing research. More specifically, let $\phi=d \log C / d \log L$ represent the change in the (weighted) number of consumers due to an immigration-induced change in the number of workers. $\phi$ can reflect a number of different ways in which immigration can affect the consumer base. For instance, immigration may lead to a substantial increase in the number of domestic consumers but only a trivial decline in the number of foreign consumers. Even if the increase in $C_{L}$ is fully offset by a decline in $C_{X}$, there may be a home bias in consumption where immigrants preference for the domestic good increases from $g_{X}$ to $g_{L}$. Changes in $\phi$ reflect these and all other possible immigrant

\footnotetext{
${ }^{8}$ Given the quasilinear utility function, product demand is not a function of income. See Borjas (2013) for an extension that includes these wealth effects.
} 
induced changes in the consumer base.

If $\phi=1$, then immigration leads to a proportionately equal increase in the size of the consumer base and the size of the workforce. Borjas (2013) refers to this case as product market neutrality. However, the impact of immigration can be non-neutral in the sense that the influx of workers can lead to a larger or smaller change in the number of consumers. For instance, if immigrants are conspicuous consumers of the domestic good than the consumer base may increase by more than the workforce $(\phi>1)$. Conversely, if the consumer base increases by less than the workforce then $\phi<1$.

From (4) the following inverse demand function is given:

$$
p=C^{\eta} Q^{-\eta}
$$

where $\eta=1-\xi>0$ is the inverse price elasticity of demand.

Assume the domestic good is produced using a Cobb-Douglas production function: ${ }^{9}$

$$
Q=K^{\alpha} L^{1-\alpha}
$$

In a competitive market, factors are paid their value of marginal product, and thus the wage and the rental rate on capital are defined as follows:

$$
w=(1-\alpha) C^{\eta} Q^{1-\eta} L^{-1},
$$

$$
r=\alpha C^{\eta} Q^{1-\eta} K^{-1}
$$

Using (7) and (8), it is possible to examine the impact of immigration on wages. Taking

\footnotetext{
${ }^{9}$ See Borjas (2013) for results using more general functional forms, including a CES production function. Since the results are similar, the simpler Cobb-Douglas production function is used here.
} 
the natural logarithm and differentiating (7) gives the following key short-run relationship between immigration and wages (i.e. the 'wage elasticity of immigration'): ${ }^{10}$

$$
\frac{d \ln w}{d \ln L}=\eta(\phi-1)-\alpha(1-\eta)
$$

From (9) we see that the wage impact of immigration depends on the labor competing effect of immigration $(\alpha)$ and on the consumer demand effect of immigration $(\phi$ and $\eta$ ). Existing studies, which usually just focus on the labor supply impact of immigration, inadvertently combine these competing effects. Thus, one of the goals of this paper is to disentangle these two effects. This can be seen more clearly by separately examining the impact of immigration on wages through each of these channels.

First, for comparison purposes, it is useful to identify the labor competing impact of immigration while holding the impact on the consumer base fixed. Specifically, if immigration does not affect consumer demand, then the wage elasticity of immigration reduces simply to (Borjas 2013):

$$
\frac{d \ln w}{d \ln L}=-\alpha
$$

Depending on the parameters $\phi$ and $\eta$, the wage impact of immigration can differ quite substantially between equations (9) and (10). For example, since labor's share of income is around 0.7, the wage impact of immigration in equation (10) is -0.3 . In contrast, assuming $\eta=0.5$ and $\phi=1$, then the wage elasticity in (9) equals -0.15 . The wage impact of immigration is attenuated due to immigration's impact on the consumer base. However, if instead $\phi=0.6$, which would occur if the consumer base increases by less than the workforce, then the wage elasticity in (9) equals -0.35 . Clearly, immigration's impact on the consumer base has important implications for the overall wage elasticity of immigration.

Second, to focus more carefully on this key relationship, it is useful to examine how

\footnotetext{
${ }^{10}$ In the short-run the capital stock is fixed $(d K=0)$. See the appendix for the long-run wage impact of immigration where instead the price of capital is fixed $(d r=0)$.
} 
changes in immigrant consumption affect wages while holding the workforce constant. Specifically, taking the natural logarithm of (7) and differentiating gives the following relationship between immigrant consumption and wages:

$$
\frac{d \ln w}{d \ln C}=\eta
$$

This generates the intuitive result that as immigrant consumption increases, while holding the workforce constant, wages increase. Conversely, and more relevant for this analysis, if immigrant consumption decreases then wages will decline. An immigrant-induced change in the consumer base is obviously important, however it is also hard to quantify. Thus, although crucially important, it is inherently difficult to measure the impact of immigrant consumption on wages.

\subsection{Remittances}

Fortunately, immigrant remittances offer a unique opportunity to identify variation in immigrant consumption while holding the workforce constant. Specifically, as immigrants send more money to foreign countries in the form of remittances, they spend less domestically, and thus the domestic consumer base will decrease. From (11) we see that as the consumer base decreases, wages decline. This leads to the following prediction:

Conjecture 1 Conditional on the workforce, remittances will reduce the domestic consumer base and decrease wages.

It is also informative to consider how the characteristics of the domestically produced good, $Q$, can affect the relationship between remittances and wages. Suppose, for instance, that $Q$ is a traded good. Since, traded goods are consumed by both domestic and foreign consumers, the consumption weights $g_{X}$ and $g_{L}$ are going to be relatively similar. Thus, remittances will have a smaller effect on the consumer base, since the foreign residents that receive the remittances will have similar preferences for the domestically produced good. Therefore, if $Q$ is a traded good, remittances will have relatively small impact on the 
consumer base and on domestic wages.

However, if $Q$ is a non-traded good than the preference for this domestically produced good is much higher among domestic consumers than foreign consumers, $g_{L}>g_{X}$. Specifically, if foreign consumers purchase none of the domestically produced good, then $g_{X}=0$. Thus, as immigrants remit money abroad, the demand for the domestically produced good will decrease substantially. Little of the money sent home by immigrants will be spent on the non-tradeable domestically produced good and thus the weighted number of consumers will decrease significantly. Therefore, if $Q$ is a non-traded good, remittances will reduce the consumer base and domestic wages by relatively more. ${ }^{11}$ This distinction between non-traded and traded goods leads to the second prediction of the model:

Conjecture 2 Conditional on the workforce, remittances will have a more negative impact on the wages of domestic workers producing non-traded goods relative to those producing traded goods.

The model laid out in this section provides a simple theoretical framework which highlights the impact of immigration on the consumer base and labor supply. However, there are some important limitations of this basic setup that are worth noting. For instance, it is assumed that the supply of the imported good $y$ is perfectly elastic and that product demand is not a function of income due to the quasilinear utility function. However, Borjas (2013) demonstrates how the inclusion of wealth effects and relaxing the assumption that the price of good $y$ is fixed can attenuate the adverse impact of immigration. More generally, Borjas (2013) shows that the predictions from this paper are broad, intuitive results that are not specific to the assumptions of this particular setup. Thus, the goal of this section has been to present a paired down framework that helps motivate and guide the empirical analysis that follows. The remainder of the paper examines whether there is empirical evidence supporting these two predictions.

\footnotetext{
${ }^{11}$ It is worth noting that if immigrant's preferences for the domestically produced good remain exactly the same after migrating, then remittances will have a limited impact on the consumer base and wages. Remittances will simply shift money from immigrant consumers with $g_{x}$ preferences to foreign consumers with the same preferences for the domestic good. In addition, there will be no difference between the impact of remittances on wages in traded and non-traded industries. The empirical results of this paper refute both of these predictions.
} 


\section{Empirical Specification}

The model highlights how immigration affects wages through labor market competition and also through changes in consumer demand. Furthermore, remittances offer a unique opportunity to identify these changes in the consumer base. Thus, the empirical analysis will test whether, conditional on the number of immigrants, an increase in the outflow of remittances from a state decreases the wages of native workers within that state. Specifically, the following equation is estimated:

$$
\ln w_{i s t}=\beta_{0}+\beta_{1} \ln r_{e m i t}+\beta_{2} \ln i m g_{s t}+\epsilon_{i s t},
$$

where $w_{i s t}$ is the real wage of native worker $i$, in state $s$, and in year $t$. The key independent variable, remit ${ }_{s t}$, is total real remittances leaving state $s$ in year $t$. Changes in remittances affect the consumer base and wages as shown in equation (11). In addition, $i m g_{s t}$ is the number of immigrants in state $s$ and year $t$. While this is not the focus of this empirical analysis, it is important to control for the number of immigrants in order to separately identify the impact of remittances.

Finally, $\epsilon_{i s t}$ is an error term which reflects factors not explicitly included in the model that may influence wages. It is assumed that $\epsilon_{i s t}$ takes the following form:

$$
\epsilon_{i s t}=\beta_{4}^{\prime} X_{i s t}+\gamma_{s}+\delta_{t}+\psi_{n}+\varepsilon_{i s t},
$$

where $X_{i s t}$ is a vector of control variables that include individual characteristics of native worker $i$, such as education, age, age squared, experience, marital status, and gender. $\gamma_{s}$ are state fixed effects, $\delta_{t}$ are year fixed effects, $\psi_{n}$ are industry fixed effects, and $\varepsilon_{i s t}$ is measurement error.

Combining these two equations generates the following empirical relationship which will be estimated using OLS:

$\ln w_{i s t}=\beta_{0}+\beta_{1} \ln r e m i t_{s t}+\beta_{2} \ln L S \_i m g_{s t}+\beta_{3} \ln H S \_i m g_{s t}+\beta_{4}^{\prime} X_{i s t}+\gamma_{s}+\delta_{t}+\psi_{n}+\varepsilon_{i s t}$. 
Here the total number of immigrants has been decomposed into the number of lowskilled immigrants $\left(L S \_i m g\right)$ and the number of high-skilled immigrants $\left(H S \_i m g\right)$. This allows for the possibility that low-skilled and high-skilled immigrants affect native wages differently.

All subsequent regressions have robust standards errors which are clustered at the stateyear level in order to account for the possibility that the error terms are correlated. This is a potential concern since the dependent variable is measured at the individual-year level while the independent variable of interest is at the state-year level. ${ }^{12}$ Finally, all regressions are weighted by individual person weights which are provided by SOEP.

This empirical strategy essentially examines whether native workers in states that experience an increase in the outflow of remittances see a decline in their wage. Given the predictions of the model, as immigrants send money abroad, the domestic consumer base will shrink, local wages will decline, and thus $\beta_{1}$ will be negative.

Despite the inclusion of state, year, and industry fixed effects and a variety of control variables, there may be lingering endogeneity concerns. For instance, an income or productivity shock within a particular state could cause native wages to increase and also enable wealthier immigrants to remit more money home. This would generate a spurious positive bias in the $\beta_{1}$ coefficient, which would, if anything, attenuate the results. However, to correct for potential endogeneity, the subsequent analysis will use an instrumental variable (IV) estimation strategy to identify the causal impact of remittances on wages. The specific construction of this instrument will be discussed in greater detail in the next section, but essentially the instrument identifies variation in remittances that is driven by foreign country factors and eliminates variation that is driven by domestic state characteristics.

To test the second prediction of the model, equation (12) is separately estimated for native workers in traded and non-traded industries. The outflow of remittances from a particular state should have a more negative impact on the wages of workers producing non-traded goods. These non-traded industries, such as services, depend more heavily on local consumption and are thus more sensitive to a reduction in demand that results from

\footnotetext{
${ }^{12}$ Additional findings reported in Table 9 show that similar results are obtained if the standard errors are clustered at the state level instead.
} 
immigrants sending money abroad.

\section{Data}

\subsection{Background}

Germany is one of the most important destination countries for migrants in the world. With over 10.7 million immigrants in 2010, Germany ranks behind only the U.S. and Russia as the top migrant destination country. ${ }^{13}$ This is due in part to the strong economic growth in West-Germany in the 1950s and 1960s which encouraged a large inflow of migrant workers from Turkey and Southern European countries. Specifically, bilateral recruitment agreements were set up between Germany and Turkey, Yugoslavia, Italy, Spain, Greece, and Portugal. Thus, not surprisingly the percentage of foreign-born workers increased in West Germany from $0.6 \%$ in 1957 to $11.2 \%$ in 1973 (Dustmann and Mestres 2010). As a result, Germany is a logical country to study when examining the impact of immigrant remittances.

Germany is also, not surprisingly, one of the most important remitting countries in the world. To make comparisons across countries a broad definition of remittances is often used which includes the sum of three components: "workers' remittances" which are private transfers from migrant workers back to the country of origin; "compensation of employees" which includes the entire income of migrants who have lived in the host country for less than a year; and "migrants' transfers" which reflects the transfer of migrants' assets from one country to another at the time of migration. ${ }^{14}$ Based on this broad definition, the World Bank finds that from 1984 to 2008, Germany remitted on average $\$ 9$ billion a year. This is third most in the world behind only the U.S. and Saudi Arabia.

While this broad definition of remittances is useful to make cross country comparisons, the analysis in this paper will focus more specifically on "workers' remittances." This narrower definition of remittances is consistent with how remittances are generally defined and avoids issues associated with including the entire income of short term migrants or the

\footnotetext{
${ }^{13}$ World Bank Migration and Remittances Factbook 2011.

${ }^{14}$ World Bank Migration and Remittances Factbook Data Notes 2011.
} 
transfer of assets in the remittance measure. Furthermore, this narrow definition of remittances is consistent with the available data from the German Socio-Economic Panel Study (SOEP).

Finally, there are a number of motives for remitting, which are nicely summarized in the survey by Rapoport and Docquier (2006). Generally, for the purposes of this paper, the motivation for remitting is less important than the simple fact that the money is leaving the German economy. However, the difference between remitting to family or remitting in order to save or invest in the origin country does matter for this analysis. The former motive will most likely decrease the consumer base as illustrated in the model however the latter motive will have a limited impact on the consumer base. The migrant may decide to save in their country of origin rather than in Germany, perhaps because they anticipate returning at some future date, but this decline in savings will not significantly affect the consumer base in Germany. Thus, the baseline specification in this analysis will focus on remittances to family members in the origin country. ${ }^{15}$

\subsection{Wages}

While there are numerous data sets that quantify the inflow of remittances into various countries, there is very little information about where these remittances are coming from. The only panel data set, that I am aware of, that has micro-level information on the outflow of remittances is the German SOEP data. ${ }^{16}$ Beginning in 1984, SOEP surveyed 5,921 WestGerman households including those with both native and foreign heads of household. These individuals have been repeatedly interviewed over the subsequent three decades. While there has been some attrition, new subsamples of representative residents have been added and thus the scale and scope of the SOEP data set is impressive. Most importantly, SOEP provides comprehensive information on wages, remittances, location, and demographic characteristics for natives and immigrants which is especially useful for this analysis. Thus, this data is unique in its ability to provide insight into the impact of immigrant remittances on

\footnotetext{
${ }^{15}$ The additional results in Table 8 confirm that remittances intended to be saved in the origin country have little impact on native wages.

${ }^{16}$ The World Bank Migration and Remittances Factbook does provide estimates on remittance outflows but only at the country level. Numerous authors have used this SOEP data including Dustmann and Mestres (2010) and D'Amuri, Ottaviano, and Peri (2010).
} 
native wages.

The key dependent variable used in this analysis is the natural logarithm of real annual labor earnings divided by annual hours worked. The sample of native workers is restricted to heads of households who are between the ages of 18 and 65. While remittances and immigration will be measured at the state-year level, the wages of native workers remain at the individual level. This allows individual demographic characteristics of the native worker, such as years of education, age, age squared, experience, marital status, and gender, to be included as control variables. ${ }^{17}$

\subsection{Remittances}

Immigrants can be defined using information on nationality or country of birth, both of which are provided by SOEP. These two measures are virtually identical, however the nationality measure has better coverage and is thus used to define an immigrant. Using nationality to define an immigrant is common in German data, however it can be problematic because if an immigrant obtains German citizenship they are no longer technically counted as an immigrant. Fortunately, SOEP follows the same individuals over time which allows me to classify a person as an immigrant if their nationality differed from German at any point in the sample. The ability to control for these changes in nationality is an important asset of the SOEP data relative to other measures of German immigration.

The remittance data from SOEP is not available for years 1992 and 1994, and the method of surveying respondents about remittances changes slightly in 1996. Despite this, the SOEP data provides the best micro-level panel data on immigrant remittances. In a given year, the weighted sum of immigrant remittances is calculated for eight West-German states. ${ }^{18}$ The weights used are the individual person weights provided by SOEP which sum to the corresponding populations in the German Mikrozensus. Thus, each immigrant remittance value is multiplied by the number of similar immigrants in the German population to generate an approximate outflow of remittance from state $s$ in year $t$. These nominal

\footnotetext{
${ }^{17}$ The SOEP experience variable is defined as full-time work experience at the time of the interview.

${ }^{18}$ The West-German states are: Berlin; Lower Saxony; North Rhine-Westphalia; Hesse; RhinelandPalatinate and Saarland; Baden-Wuerttemberg; and Bavaria. Rhineland-Palatinate and Saarland are treated as one geographic unit in the SOEP data.
} 
remittance sums are then deflated using the German Consumer Price Index $(2005=100)$ available from OECD.stat. Finally, the natural logarithm of this is taken to generate the following remittance variable:

$$
\ln \text { remit }_{s t}=\ln \left[\frac{\sum_{i}\left(\text { remittances }_{i s t} * \text { person_weight }_{\text {ist }}\right)}{C P I_{t}}\right] .
$$

This is the key independent variable in the analysis that follows. ${ }^{19}$

\subsection{Immigration}

To estimate the impact of remittances on native wages it is important to control for the number of immigrants. Specifically, new immigrants may lead to an increase in the outflow of remittances and they can directly reduce wages through the labor competing channel identified in the model. Thus, if not adequately controlled for in the empirical specification, new immigrants could lead to an omitted variable bias.

Using the SOEP data and the relevant person weights, the natural log of the number of low-skilled and high-skilled immigrants between the ages of 18 and 65 is calculated for each state and year. Low-skilled immigrants are defined as those with 10 years or less of education and high-skilled immigrants are those with more than 10 years of education. This splits the sample of immigrants roughly in half, although the results are robust to other definitions. Following the predictions of the model, these control variables capture an immigrant induced change in the workforce. However, the results that follow are similar if instead the total number of immigrants, the overall size of the workforce, or the immigrant share of the workforce are used as controls.

\subsection{Descriptive Statistics}

The SOEP data used in this analysis includes 23 years (1984-2008, excluding 1992 and 1994) and spans 8 different West-German states. One drawback of the SOEP data is that it is a

\footnotetext{
${ }^{19}$ While this is the preferred method for constructing this remittance variable, the results are similar if an unweighted measure or a remittance per person measure are used instead.
} 
relatively small longitudinal data set and thus there are concerns about how representative it is of the overall German population. Fortunately there are a number of features of the data that mitigate these concerns. First, numerous subsamples have been added to the original SOEP data set to ensure that it is representative of the overall population. Second, SOEP provides individual person weights which reflect how common each individual is in the German population. Thus, using these person weights, it is possible to estimate the overall immigrant population and the total outflow of remittances from each state. Third, based on recommendations from SOEP, this analysis will focus on the more populous West-German states which have a relatively large sample size. ${ }^{20}$

Fourth, the SOEP immigration measure is consistent with an external measure of the foreign population produced by the Federal Statistical Office of Germany (Destatis). ${ }^{21}$ Specifically, Figure 1 shows that the West-German immigrant measure produced by Destatis and the one calculated using the SOEP data are very similar. The slightly different trends towards the end of the sample could reflect the fact that immigrants who receive German citizenship are no longer counted as foreigners by Destatis but would still be included in the SOEP immigrant measure. Overall, Figure 1 demonstrates that despite it's relatively small sample size, the SOEP data generates an estimate of the immigrant population that is quite precise. Furthermore, this indicates that the SOEP person weights, which are used to calculate the immigration and remittance variables, are accurate.

On average, immigrants that choose to remit send 1,917 euros abroad which represented $11 \%$ of their income. These individual remittances are aggregated to the state-year level and then the empirical analysis exploits changes in remittances from these West-German states over time. Figure 2 shows the average number of immigrants and the average outflow of remittances from the West-German states included in the sample. There are substantial differences across states. For instance, North Rhine-Westphalia has a large immigrant population and a large outflow of remittances while Berlin has less of both. In addition,

\footnotetext{
${ }^{20}$ Given the lack of remittance data and the small sample size, East German states were not included in the analysis. The West-German states of Schleswig-Holstein, Hamburg, and Bremen are not included in the baseline specification due to a lack of remittance data. However, these West-German states are included in a robustness analysis reported in Table 9.

${ }^{21}$ Destatis graciously provided this data on the foreign population, however data for the years 1988-1991 are not available.
} 
relative to the size of the immigrant population, Bavaria remits a lot while RhinelandPalatinate and Saarland remit little. Although Figure 2 provides insight into the data, many of these differences across states will be absorbed by the state fixed effects in the analysis that follows.

Figure 3 shows the average number of immigrants and the average flow of remittances by foreign country. There are a large number of immigrants from Turkey, the former Yugoslavia, Greece, Italy, and Spain. This is not surprising given the bilateral recruitment agreements and the subsequent inflow of immigrants into Germany from these countries. Thus, immigrants from these countries are significantly represented in the SOEP sample and remittances to these countries are relatively large. In addition, Figure 3 identifies some interesting differences across these countries. For instance, given the size of the immigrant population, remittances to Yugoslavia are large while remittances to Italy are relatively small. $^{22}$

Figures 2 and 3 provide insight into remittances which is the key independent variable. It is also informative to look at the characteristics of the 12,853 native German household heads included in the sample. The summary statistics of these native workers are reported in Table 1. There is substantial variation in individual native wages which is the key dependent variable. The analysis that follows examines to what extent these fluctuations in wages are a function of the outflow of remittances from that state. Table 1 also provides summary information on the individual demographic control variables included in the empirical analysis. Specifically, native household heads have on average 12 years of education, are 44 years old, and have 18 years of experience. In addition, $61 \%$ of the native heads of households are married and $68 \%$ are male.

\subsection{Instrument}

Variation in immigrant remittances is likely driven both by factors in the foreign country and by German economic conditions. Since the latter effect is almost certainly correlated with German wages, it would be appealing to identify and use the variation in remittances

\footnotetext{
${ }^{22}$ It is assumed that immigrants send remittances to their country of origin. In the descriptive statistics Yugoslavia is treated as one country. However, in the IV analysis that follows remittances are more carefully assigned to specific countries within the former Yugoslavia.
} 
that is due to foreign country factors. To gain a sense of the remittance data in these two important dimensions, Figures 4 and 5 plot remittances by German source state and by foreign destination country.

Specifically, Figure 4 plots the change in remittances per immigrant from West-German states over time. Consistent with the evidence from Figure 2, some states on average remit more than other states. In addition, there is substantial variation in the outflow of remittances from these states over time. This variation in remittances is potentially problematic for this analysis since it will not be captured by the state or year fixed effects. For instance, strong economic growth in a particular German state could increase native wages and lead to wealthier immigrants remitting more.

Figure 5 plots the change in remittances per immigrant by destination country over time. Consistent with Figure 3, German immigrants remit more to some foreign countries than others. In addition, remittances to these different foreign countries changes over time which is especially useful for this analysis. Specifically, this provides a source of exogenous variation in remittances that is unrelated to domestic economic conditions in Germany. ${ }^{23}$

There are a number of events in these foreign countries that likely influenced the change in remittances observed in Figure 5. ${ }^{24}$ For instance, in 1999 a powerful 7.4 magnitude earthquake struck the Turkish city of Izmit. The earthquake killed 17,000 people, injured 50,000 , left 500,000 people homeless, and caused $\$ 3$ to $\$ 6.5$ billion of damage. ${ }^{25}$ Not surprisingly, Turkish immigrants in Germany remitted more money home after this devastating earthquake. Similarly, remittances from Yugoslavian immigrants are relatively high in the 1990's as Yugoslavia broke apart and plunged into war. In addition, remittances to Bosnia and Herzegovina, increased from 2003-2005 after those that committed war crimes during the 1990s were sentenced to jail and formal apologies were issued. Finally, the enthusiasm over Italy winning the 2006 World Cup, which was hosted by Germany, may explain the surge in Italian remittances in 2006.

\footnotetext{
${ }^{23}$ Yang (2008) uses exchange rate shocks to identify an exogenous source of variation in remittance inflows into the Philippines. While similar in spirit, this analysis uses a more general fixed effects approach to capture a variety of foreign country factors that could influence the outflow of remittances.

${ }^{24}$ By no means are these are the only or even the most important events influencing remittances. Rather they are simply some examples that may have affected remittances and that help motivate the choice of instrument used in this analysis.

${ }^{25}$ Source: U.S. Geological Survey (http://neic.usgs.gov/neis/eq_depot/1999/eq_990817/)
} 
These country specific events are likely exogenous to German wages and are thus useful for this analysis. One practical difficulty is that the source of these country specific shocks vary substantially and could include a wide range of factors, such as natural disasters, wars, elections, exchange rate fluctuations, foreign economic conditions, and even sporting events. Rather than trying to measure each of these factors individually, which would be difficult, this analysis uses a more general fixed effect strategy to identify variation in remittances that is driven by foreign country characteristics.

Specifically, for each immigrant who remitted money abroad, there is data on their West-German state of residence and their country of origin. Thus, in order to construct the instrument, individual immigrant remittances are regressed on state*year fixed effects and country*year fixed effects. The state*year fixed effects in this regression capture changes in remittances that are common to immigrants within a particular state in a given year. Since the goal is to eliminate the variation in remittances that could be driven by unobserved factors at the state level which may be correlated with wages, these state*year fixed effects are discarded.

Instead, the coefficients on the country*year fixed effects are used to construct the instrument. This captures changes in remittances that are driven by foreign country characteristics and that are exogenous to local economic conditions. For instance, the 1999 earthquake in Izmit caused Turkish immigrants to send more money home to family and friends regardless of the German state that the immigrant lived in. This variation in remittances would be captured by the country*year fixed effect but not by the state*year fixed effect. Using the coefficients on these country*year fixed effects, the weighted sum of predicted remittances is then calculated for each state-year observation. ${ }^{26}$ This weighted sum is then divided by the CPI and logged in the manner outlined in (11), which generates the remittance instrument.

The scatter plots in Figure 6 show how actual remittances and the remittance instrument are related to native wages. First, the average native wage is calculated at the state-year

\footnotetext{
${ }^{26}$ Prior to the summation, a constant is added to the predicted remittance values to ensure that they are all positive. This is necessary so that when the instrument is logged the values are not converted to missing. As long as all the predicted remittance values are positive, the results are not sensitive to the size of the constant.
} 
level. Then the residuals are obtained from separately regressing the average native wage, remittances, and the remittance instrument on state and year fixed effects. These residuals reflect the variation exploited in this analysis, namely the change in wages and remittances over time within a state.

In the top scatter plot in Figure 6 there is little relationship between native wages and remittances. However, in the bottom scatter plot, there is a negative relationship between native wages and the remittance instrument which is consistent with the predictions of the model. The difference between these two scatter plots suggests that endogeneity is in fact leading to a spurious positive bias in the relationship between wages and remittances. The instrument overcomes this bias by identifying an exogenous source of variation in remittances and thus there is a more negative relationship in the bottom scatter plot. While these contrasting scatter plots are intriguing, certainly a more rigorous econometric analysis is necessary.

\section{$5 \quad$ Results}

\subsection{Wages and Remittances}

The OLS results from estimating (12) are reported in Table 2. All specifications have robust and clustered standard errors in brackets, include state, year, and industry fixed effects, and are weighted by the person weights provided by SOEP. Column 1 excludes the controls while column 2 includes immigration and the individual demographic characteristics of the native worker. Consistent with the first prediction of the model, both specifications indicate that immigrant remittances have a significant negative impact on the wages of native Germans. For instance, the results in column 2 indicate that a one percent increase in the outflow of remittances from a particular state leads to a $0.027 \%$ decline in the wages of native workers within that state.

The significant negative impact of remittances on wages observed in Table 2 is consistent with the predictions of the model. An increase in remittances, reduces the domestic consumer base, which in turn decreases native wages. It is surprising that such a negative and significant relationship emerges in these basic OLS results. The most obvious endogeneity 
concerns discussed earlier should if anything generate a spurious positive bias in these OLS coefficients.

Interestingly, the coefficient on low-skilled immigration in column 2 of Table 2 is insignificant. This is consistent with a number of previous studies (Friedberg and Hunt 1995, Card 2005, Ottaviano and Peri 2012) and especially with D'Amuri et al. (2010) who find that immigration into Germany during this period did not depress the wages of native workers. In contrast, the results in Table 2 suggest that high-skilled immigration has a positive impact on native wages. This is consistent with existing evidence that shows that high-skilled immigrants increase productivity, innovation, and thus native wages (Peri et al. 2013, Hunt 2011, Kerr and Lincoln 2010). ${ }^{27}$ In addition, the coefficients on the demographic controls are significant and of the expected sign. Wages are increasing with education, age (although decreasing with age squared), and experience. In addition, those that are married and male earn relatively more.

The IV analysis will address endogeneity concerns by identifying a causal impact of remittances on wages. The first stage IV results are presented in Table 3 and indicate that the remittance instrument is a good predictor of actual remittances. In both specifications, the coefficient on the remittance instrument is positive and significant at the one percent level. The F-stat on the excluded instrument is above 60 in both specifications, which indicates a strong instrument. One potential concern with this instrument is that the exclusion restriction could be violated if a shock in the foreign country caused people to migrate to Germany. These new immigrants could adversely affect wages, which would mean that the foreign country characteristics could affect wages through a channel other than remittances. Fortunately, this empirical specification controls for the number of immigrants and thus alleviates these concerns.

The second stage IV results are reported in Table 4. The results in both columns include state, year, and industry fixed effects while column 2 also includes the controls. Both specifications indicate that remittances have a significant negative impact on native wages. Specifically, the results in column 2 indicate that a one percent increase in remittances leads

\footnotetext{
${ }^{27}$ Despite the fact that this analysis is not well-suited to examine the impact of immigration on similarly skilled native workers and does not address the endogeneity of the immigrant location decision, the results in Table 2 are certainly consistent with existing evidence on the wage impact of low and high skilled immigrants.
} 
to a $0.056 \%$ decrease in the wages of native workers. This result is, again, consistent with the first prediction of the model. As German immigrants remit more money abroad, the domestic consumer base shrinks, and thus domestic wages fall.

While the coefficient on remittances is negative in both the OLS and IV specifications, the IV results are more negative. This is consistent with endogeneity leading to a spurious positive bias in the OLS coefficients. Specifically, a local income shock within a state likely increases native wages and leads to wealthier immigrants remitting more. However, in the IV analysis the variation in remittances is driven only by exogenous factors in the foreign country and thus this spurious positive bias is eliminated. Therefore, not surprisingly, the remittance coefficients in the IV regressions in Table 4 are more negative than the OLS results from Table 2. However, both the OLS and IV results indicate that remittances have a negative and significant impact on local wages which confirms the first prediction of the model.

A simple back of the envelope calculation can provide insight into whether the magnitude of these results are plausible. Immigrants represent about $12 \%$ of the German population in the sample and suppose they remit approximately $11 \%$ of their income. Thus, remittances represent about $1.3 \%$ of German income which implies that a one percent increase in remittances decrease German income by $0.013 \%$. The OLS and IV results in Tables 2 and 4 indicate that this one percent increase in the outflow of remittances will ultimately lead to between a $0.027-0.056 \%$ decrease in wages. This implies a Keynesian multiplier of between 2 - 4. Although this is a crude back of the envelope calculation, it suggests that the magnitude of this result is reasonable.

An intriguing aspect of the results in Tables 2 and 4, is that the remittance coefficient is negative and significant while the low-skilled immigration coefficient is not. Certainly more work is needed, but this comparison provides preliminary evidence that suggests that immigration's impact on the consumer base may be relatively important. At the very least these results indicate that future research should more carefully differentiate between the labor competing impact of immigration and the consumer base impact of immigration. 


\subsection{Traded and Non-Traded Industries}

According to the second prediction of the model, remittances should have a more negative impact on native wages in non-traded industries since these industries are more reliant on domestic consumption. Traded industries are less sensitive to changes in domestic consumption and foreign residents who receive the remittances can still purchase these traded goods. Thus, the second proposition is tested by comparing the impact of remittances on the wages of workers in traded and non-traded industries.

Column 1 of Table 5 reports the OLS results when the sample is limited to workers in traded industries and column 2 reports the OLS results when the sample is limited to workers in non-traded industries. ${ }^{28} \mathrm{~A}$ one percent increase in remittances has no impact on the wages of native workers in traded industries but decreases the wages of native workers in non-traded industries by $0.034 \%$. This is consistent with the second prediction of the model that remittances will have a more substantial impact on the demand for non-traded goods and thus more adversely affect the wages of workers in these industries. The IV results for the traded and non-traded industries are reported in columns 3 and 4 respectively. Again there is a more negative impact of remittances on the wages of native workers in non-traded industries, although now both coefficients are significant.

A potential concern with this IV analysis is that the exclusion restriction could be violated if a foreign country shock changed the demand for German traded goods. This would be problematic since a foreign shock could affect German wages through a channel other than remittances. For instance, a negative GDP shock in Turkey may decrease their demand for German goods, which could depress wages in German traded industries. ${ }^{29}$ However, this would, if anything, work against the findings in Table 5 since this would only generate a spurious negative bias in the remittance coefficient in the traded industry specification.

Overall, the results in Table 5 provide further evidence that remittances decrease wages and indicate that the impact is strongest in industries that are more dependent on local

\footnotetext{
${ }^{28}$ Traded industries include Agriculture, Trade, Mining, Transport, Manufacturing, Energy, and Finance, while non-traded industries are Services, Construction, and Other. The results are robust to alternate definitions of traded and non-traded industries.

${ }^{29}$ Technically, to be problematic the reduction in demand for German traded goods has to occur in the German states that have a higher proportion of Turkish immigrants, which seems unlikely. These states are where the shock to remittances, driven by a fall in Turkish GDP, will be relatively large.
} 
consumption.

\section{Extensions}

\subsection{Industry Output}

The results so far indicate that remittances depress the wages of native workers, particularly of those working in non-traded industries. The intuition is that remittances reduce the consumer base and thus depress native wages. To verify that the observed relationship between remittances and wages is operating through this channel, it would be nice to confirm that output is also declining in response to remittances. Furthermore, remittances should have a larger impact on the output of non-traded industries since these sectors are more reliant on domestic consumption. This section tests these predictions.

Industry level value added data by West German state was obtained from the Federal Statistical Office of Germany (Destatis). Unfortunately, this data is only available after 1990 which restricts the sample. However, for each state and year it is possible to construct total output, traded output, and non-traded output which correspond to the industry groups defined earlier. Thus, using this data it is possible to examine how the outflow of remittances affects industry output within that state after controlling for state and year fixed effects.

The results in column 1 of Table 6 confirm that an increase in remittances leads to a reduction in output. Furthermore, the results in column 2 show, not surprisingly, that remittances have little impact on the output of traded industries. However, remittances have a significant negative impact on the output of non-traded industries, which are more reliant on domestic consumption. Specifically, a one percent increase in the outflow of remittances from a particular state leads to a $0.025 \%$ decline in the output of non-traded industries within that state.

The results in Table 6 provide confirmation that remittances are affecting wages through their impact on domestic consumption. Furthermore, this impact is strongest among industries most reliant on domestic consumption. Finally, the fact that these results are found using an entirely different data set on industry level output provides external validation for the predictions of the model and the baseline results. 


\subsection{Unionized Industries}

Although their relevance is declining, trade unions still play an important role in the German labor market. According to OECD.stat, the share of German workers who are members of a trade union was on average $28 \%$ during the 1984-2008 period. These unions bargain for higher wages and negotiate for employment protections on behalf of their workers. Furthermore, generally all employees within a firm or industry are covered by the collective bargaining agreement regardless of whether they are union members or not. As a result, heavily unionized industries will experience less flexible wages. Thus, remittances should have a stronger effect on the wages of workers in non-unionized industries.

Fortunately, SOEP periodically asks whether respondents are members of a trade union. Using this data, the industries are split into unionized and non-unionized groups based on their average unionization rates. ${ }^{30}$ Table 7 separately reports the impact of remittances on the wages of workers in unionized and non-unionized industries. Columns 1 and 2 present the OLS results and columns 3 and 4 present the IV results. Consistent with expectations, remittances have an insignificant impact on the wages of native workers in unionized industries but a negative and significant impact on the wages of native workers in non-unionized industries. The non-unionized industries have less rigid wage structures and thus changes in the consumer base have a stronger impact on the wages of workers in these industries.

Overall, the results in Tables 5-7 are reassuring since they show that the impact of remittances on wages is strongest in the expected industries. Specifically, changes in the consumer base have a larger impact on the wages of workers in non-traded and non-unionized industries.

\subsection{Savings Remittances}

The analysis so far has focused on immigrant remittances to family members. However, prior to 1996, SOEP also provides data on remittances for the purpose of saving. Remittances

\footnotetext{
${ }^{30}$ Since this question is not asked every year, it is not possible to include union membership as a control variable. Unionized industries include Mining, Energy, Transport, Manufacturing, and Construction, while non-unionized industries include Agriculture, Trade, Finance, Services, and Other.
} 
for savings purposes were not included in the baseline analysis in order to be consistent with the post-1996 data and to be consistent with the type of remittances envisioned in the model. Furthermore, it is unlikely that remittances motivated by the desire to save in the foreign country would significantly affect the domestic consumer base in the short run. This type of remittances simply reduces domestic savings and thus should have little impact on native wages.

Using the pre-1996 data, it is possible to compare how these two different types of remittances affect native wages. Columns 1 and 2 of Table 8 report the OLS results obtained by regressing native wages on the two different components of remittances. In column 1 , remittances to family members still has a significant negative impact on native wages despite the smaller sample. A one percent increase in remittances to family members reduced native wages by $0.066 \%$. However, in column 2 remittances for savings purposes has an insignificant impact on native wages in the short run. This is consistent with the hypothesis that remittances motivated by the desire to save abroad are unlikely to affect the domestic consumer base and thus do not depress native wages.

The analogous IV results are presented in columns 3 and 4 of Table 8. In column 3, the coefficient on family remittances is significant and more negative than the OLS results, as expected. In column 4, remittances for savings purposes has an insignificant impact on native wages due in part to a weak first stage. In other words, foreign country shocks are a poor predictor of saving remittances. This is not surprising since the decision to remit savings back to the country of origin is likely motivated by personal reasons, such as an anticipated return migration, and has less to do with foreign country shocks.

Overall, the results in Table 8 indicate that remittances to family members decreases native wages, as expected. However, remittance motivated by the desire to save abroad has a limited impact on the domestic consumer base, does not respond to foreign country shocks, and has an insignificant impact on native wages.

\subsection{Sensitivity Analyses}

Table 9 reports results from a variety of sensitivity analyses. First, an alternate instrument is constructed which more carefully identifies shocks in the foreign country. The concern 
is that the country*year fixed effects may be capturing more than just foreign country shocks especially if immigrants differ systematically by country of birth. To account for this possibility, additional controls are included in the preliminary regression used to construct the instrument. Specifically, individual remittances are regressed not only on country*year and state*year fixed effects but also on industry*year fixed effects and on the education, age, age squared, experience, marital status, and gender of the immigrant. ${ }^{31}$ As before, the country*year fixed effects will capture foreign country shocks and will be used to construct the instrument. Column 1 of Table 9 reports the IV results using this alternate instrument. The coefficient on remittances remains negative, significant, and is similar in magnitude to the baseline result.

Since SOEP repeatedly surveys the same individuals over time it is possible to include individual person fixed effects in the empirical analysis. This will control for unobserved individual characteristics that do not vary over time, such as innate skill or ability. The inclusion of person fixed effects is asking a lot of the data since an additional 9,543 right hand side dummy variables are added to the regression. The results, which are reported in column 2 of Table 9, show that remittances have a significant, negative impact on native wages. ${ }^{32}$ Using a very different empirical specification, the estimated impact of remittances on native wages remains similar to the baseline results.

Based on the recommendation from SOEP, the baseline sample was restricted to the larger West-German states that have the most comprehensive data on immigrants and remittances. Thus, the states of Schleswig-Holstein, Hamburg, and Bremen were excluded from the baseline analysis. Column 3 of Table 9 reports the results when these three states are included in the sample. Not surprisingly, the coefficient on remittances is attenuated when these outlier observations are incorporated into the analysis. However, it remains negative and significant at the one percent level.

\footnotetext{
${ }^{31}$ This initial regression used to construct the instrument shows that immigrant remittances are increasing with education, age, and male but decreasing with married.

${ }^{32}$ The inclusion of person fixed effects is problematic since the number of regressors in the first stage is now greater than the number of clusters. This means that the covariance matrix is not of full rank. To address this issue, all of the fixed effects are first partialled out from the other variables and instruments. By the Frisch-Waugh-Lovell theorem this does not affect the coefficients but it means the covariance matrix is of full rank and thus the IV specification can be estimated with the inclusion of person fixed effects. One minor implication is that the R-squared using this method is small.
} 
The baseline analysis clustered the standard errors at the state-year level. However, it is also possible to cluster the standard errors at the state level instead which will account for potential autocorrelation in the data. The drawback is that there will only be 7 clusters which is far fewer than is recommended. Column 4 of Table 9 reports the results with standard errors clustered at the state level. Despite the limited number of clusters, the coefficient on remittances remains significant.

The fall of the Berlin wall was clearly an important event in Germany during this period. However, since this analysis focuses on remittances from immigrants who live in West-German states, German reunification and any potential internal migration thereafter is unlikely to affect these results. ${ }^{33}$ With that said, just as an additional check, it is possible to exclude from the analysis any East-German citizen who has migrated to a West-German state. As expected, the results in column 5 show that the exclusion of these East-Germans does not affect the results.

Finally, column 6 of Table 9 controls for immigrants based on their country of origin rather than their skill level. Although the skill level of the immigrant seems more relevant for this type of wage analysis, it is possible that a change in remittances could be driven by an influx of immigrants from a particular country who are more or less likely to remit. Controlling for immigrants based on their country of origin will account for these types of compositional changes. However, the coefficient on remittances in column 6 remains significant and virtually unchanged, which alleviates concerns that the results are being driven by the composition of immigrants within a state.

Overall, the results in Table 9 show that the key results of this paper are remarkably robust. Specifically, the coefficient on remittances in Table 9 remains negative and significant in all six empirical specifications. Consistent with the prediction of the model, these results show that an increase in remittances reduces the consumer base and depresses native wages.

\footnotetext{
${ }^{33}$ East-Germans who live in West-Germany are not defined as immigrants in the SOEP data set.
} 


\section{Conclusion}

This paper makes two important contributions to the existing literature. First, it provides insight into the impact of remittances on the source country, rather than on the foreign country receiving the remittances. Second, in contrast to existing studies, it focuses on how immigration affects the domestic consumer base rather than on the labor market competing impact of immigration.

The model shows that the effect of immigration on wages depends crucially on immigration's impact on consumer demand. Remittances represent a unique way of identifying variation in consumer demand, since they reduce the consumer base but have no impact on the size of the workforce. Thus, the model predicts that as remittances increase, the consumer base shrinks, and domestic wages decline. Furthermore, since non-traded industries are more dependent on local consumption, remittances will have a more negative impact on the wages of workers in these industries.

The predictions of the model are tested using an unusual German data set that includes micro-level information on remittances. Despite the potential spurious positive bias, the OLS results indicate that remittances have a negative and significant impact on native wages. The IV results, which eliminate these endogeneity concerns by focusing on variation in remittances driven by foreign country factors, indicate a more negative relationship. Together these results show that a one percent increase in remittances reduces native wages by $0.03-0.06 \%$. Finally, as expected, remittances have a more negative impact on the wages of native workers in non-traded, non-unionized industries.

Although this paper finds that remittances depress native wages, these results should not be viewed as a rational for policy makers to restrict remittances. First, the benefits to developing countries are large and well documented. Remittance inflows accounted for $2 \%$ of GDP in developing countries and for $5.4 \%$ of GDP in low-income countries in 2009. ${ }^{34}$ Thus, the modest decline in wages in developed countries due to the outflow of remittances is a trade-off many should be willing to make. Second, there could be unintended consequence of restricting remittances. Without the ability to remit, an important rational for migrating

\footnotetext{
${ }^{34}$ Migration and Remittances Factbook 2011, World Bank.
} 
could be undermined. A decline in immigration could have negative implications for a host country like Germany. Alternatively, without the ability to remit, migrants may bring their families with them to the host country which could put a strain on social services. Thus, the goal of this analysis is not to critique remittances themselves, since the benefits likely exceed the costs, but rather to provide the first careful assessment of these costs.

While the results of this paper focus specifically on the relationship between remittances and wages, the implications of these results are broader. They highlight the important impact that immigration can have on the consumer base. Immigrants may compete with native workers for jobs but they also consume goods and services which can alleviate the labor market competing impact of immigration. An alternate interpretation of the results in this analysis, is that as the domestic consumer base grows, native wages increase. At the very least, this paper indicates that future research should think more carefully about the implications of immigration on consumption. 


\section{References}

Ahmed, Faisal Z. 2012. "Remittances Deteriorate Governance." The Review of Economics and Statistics, forthcoming.

Amuedo-Dorantes, Catalina and Susan Pozo. 2006. "Migration, Remittances, and Male and Female Employment Patterns." The American Economic Review, 96(2): 222-226.

Borjas, George J. 2003. "The Labor Demand Curve is Downward Sloping: Reexamining the Impacts of Immigration on the Labor Market." Quarterly Journal of Economics, 118(4): $1335-74$.

Borjas, George J., Richard B. Freeman, and Lawrence F. Katz. 1997. "How Much Do Immigration and Trade Affect Labor Market Outcomes?" Brookings Papers on Economic Activity, 1997(1): 1-90.

Borjas, George J. 2013. "The Analytics of the Wage Effect of Immigration." IZA Journal of Migration, 2: 22.

Card, David. 1990. "The Impact of the Mariel Boatlift on the Miami Labor Market." Industrial and Labor Relations Review, 43(2): 245-57.

Card, David. 2005. "Is the New Immigration Really so Bad?" The Economic Journal, 115(507): F300-23.

Chami, Ralph, Adolfo Barajas, Thomas Cosimano, Connel Fullenkamp, Michael Gapen, and Peter Montiel. 2008. "Macroeconomics Consequences of Remittances." International Monetary Fund Occasional Paper Number 259.

de la Briere, Benedicte, Elisabeth Sadoulet, Alain de Janvry, and Sylvie Lambert. 2002.

"The Roles of Destination, Gender, and Household Composition in Explaining Remittances: an Analysis for Dominican Sierre." Journal of Development Economics, 68(2): 309-328. 
D'Amuri, Francesco, Gianmarco I.P. Ottaviano, and Giovanni Peri. 2010. "The Labor Market Impact of Immigration in Western Germany in the 1990s." European Economic Review, 54(4): 550-570.

Dustmann, Christian and Josep Mestres. 2010. "Remittances and Temporary Migration." Journal of Development Economics, 92(1): 62-70.

Friedberg, Rachel M. and Jennifer Hunt. 1995. "The Impact of Immigrants on Host Country Wages, Employment and Growth." Journal of Economic Perspectives, 9(2): 23-44.

Funkhouser, Edward. 1995. "Remittances from International Migration: A Comparison of El Salvador and Nicaragua." The Review of Economics and Statistics, 77(1): 137-146.

Hanson, Gordon H. 2007. "Emigration, Remittances, and Labor Force Participation in Mexico." Integration and Trade Journal, 27: 73-103.

Hong, Gihoon and John McLaren. 2013. "Are Immigrants a Shot in the Arm for the Local Economy?" University of Virginia Working Paper.

Hunt, Jennifer. 2011. "Which Immigrants are Most Innovative and Entrepreneurial? Distinctions by Entry Visa." Journal of Labor Economics, 29(3): 417-457.

Kerr, William R. and William F. Lincoln. 2010. "The Supply Side of Innovation: H-1B Visa Reform and US Ethnic Invention." Journal of Labor Economics, 28(3): 473-508.

Lucas, Robert E. B. and Oded Stark. 1985. "Motivations to Remit: Evidence from Botswana." Journal of Political Economy, 93(5): 901-918.

Mazzolari, Francesca and David Neumark. 2012. "Immigration and Product Diversity." Journal of Population Economics, 25(3): 1107-1137.

Olney, William W. 2013. "Immigration and Firm Expansion." Journal of Regional Science, $53(1): 142-157$.

Osili, Una Okonkwo. "Remittances and Savings from International Migration: Theory and Evidence Using a Matched Sample." Journal of Development Economics, 83(2): 446-465. 
Ottaviano, Gianmarco and Giovanni Peri. 2012. "Rethinking the Effects of Immigration on Wages." Journal of the European Economic Association, 10(1): 152-197.

Peri, Giovanni, Kevin Shih, and Chad Sparber. 2013. "STEM Workers, H1B Visas and Productivity in US Cities" UC Davis Department of Economics Working Paper.

Rapoport, Hillel and Frederic Docquier. 2006. "The Economics of Migrants' Remittances." Handbook on the Economics of Giving, Reciprocity and Altruism, Volume 2, 1135-1198.

The World Bank. 2008. "Remittances and Development, Lessons from Latin America." Edited by Pablo Fajnzylber and J. Humberto Lopez.

Yang, Dean. 2008. "International Migration, Remittances and Household Investment: Evidence from Philippine Migrants' Exchange Rate Shocks." The Economic Journal, 118: 591-630.

Yang, Dean. 2011. "Migrant Remittances." Journal of Economic Perspectives, 25(3): 129152. 
FIGURE 1

Comparing German Destatis and SOEP Immigration Data

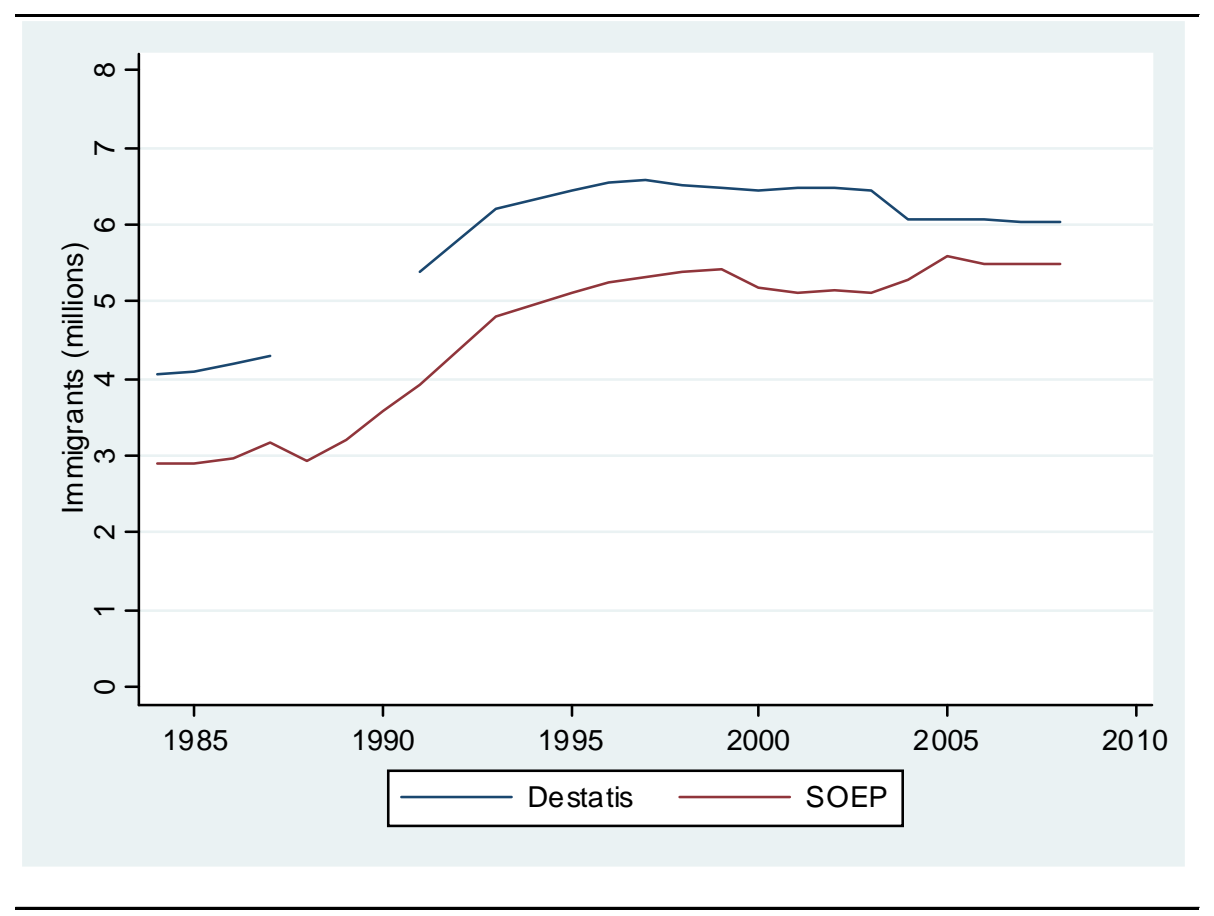

The Destatis immigration variable measures the total "foreign population" of 8 West-German states. The SOEP immigration variable uses the person weights to measure the total foreign born population in $8 \mathrm{West-German}$ states. 
FIGURE 2

Immigrants and Remittances by West-German State

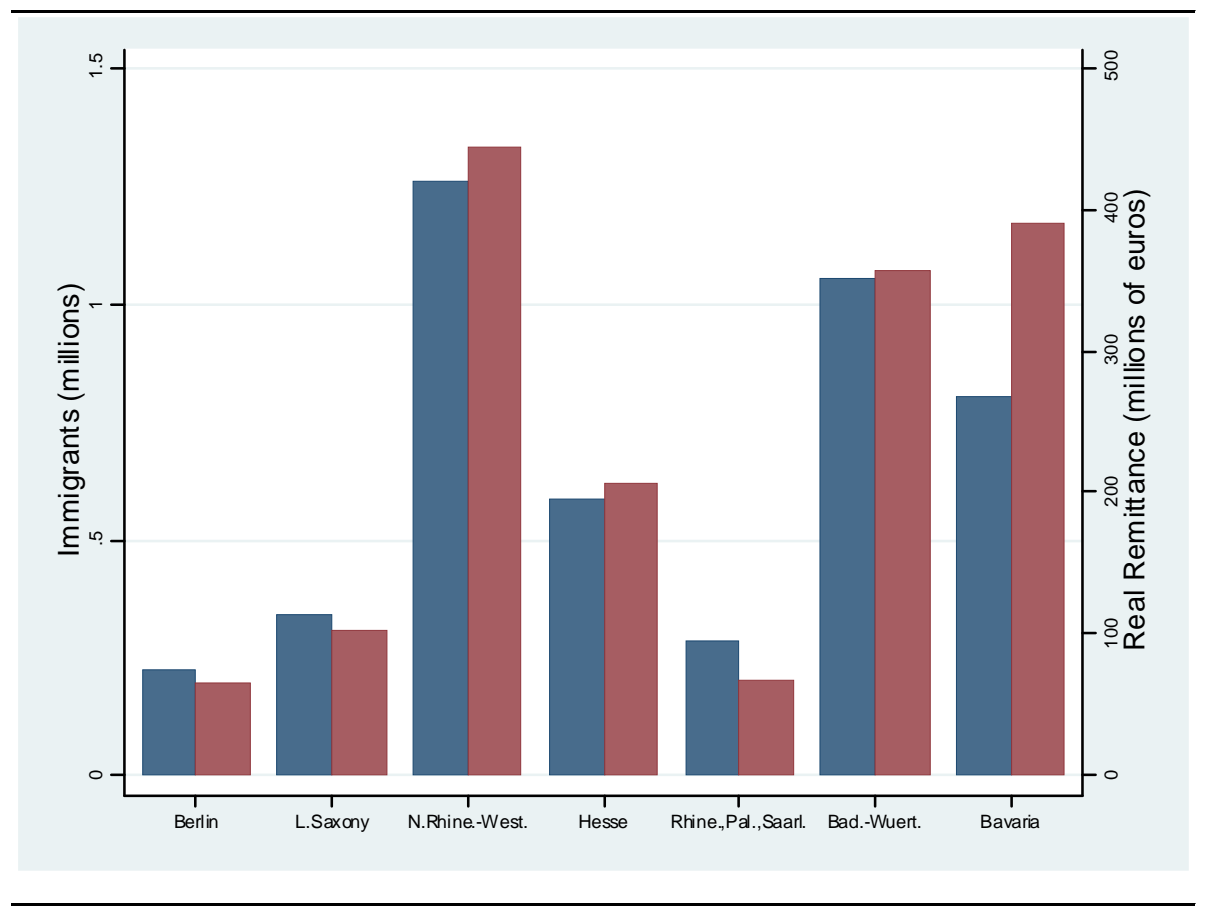

Average number of immigrants and the average outflow of real remittances by WestGerman state, calculated using individual person weights provided by SOEP. 
FIGURE 3

Immigrants and Remittances by Foreign Country

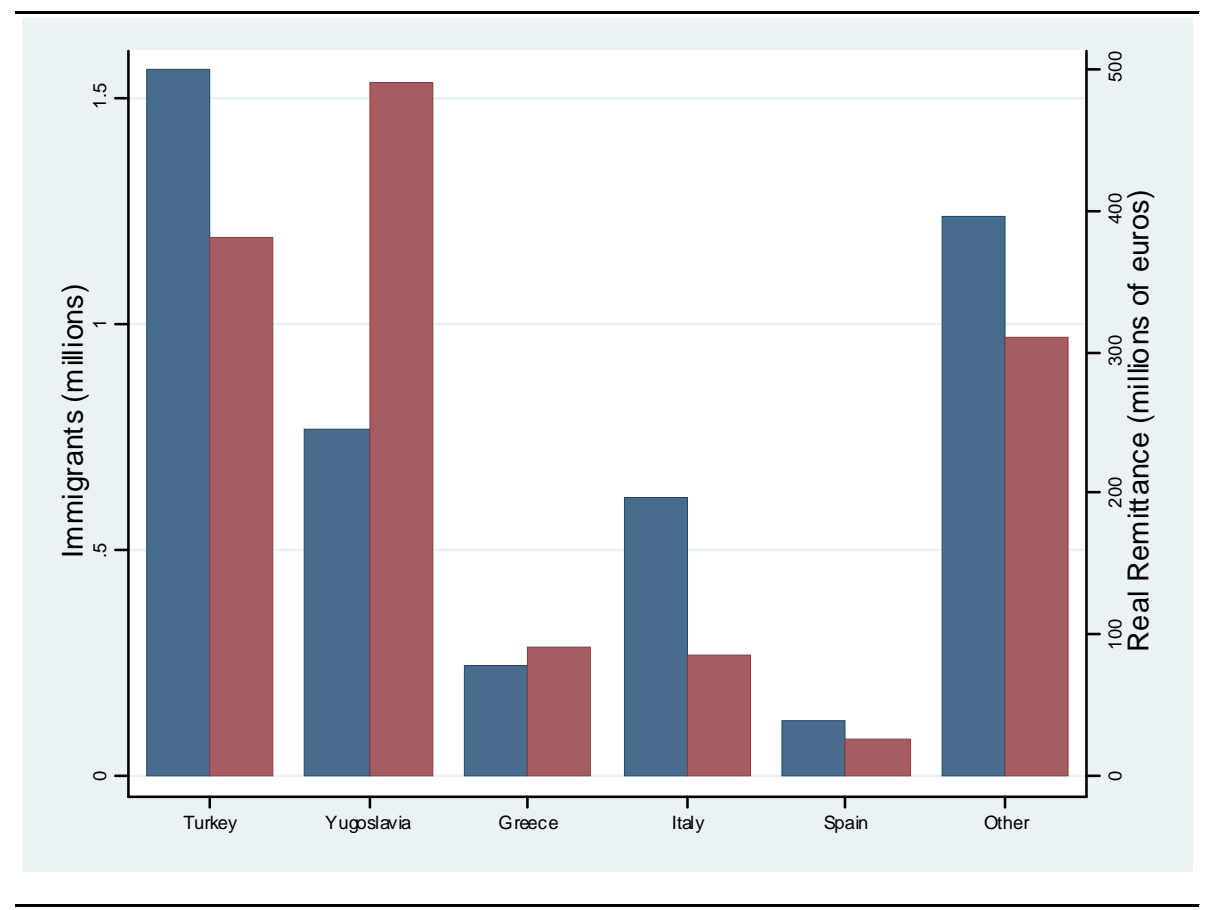

Average number of immigrants and average real remittances by foreign country, calculated using individual person weights provided by SOEP. 
FIGURE 4

Remittances per Immigrant by West-German State

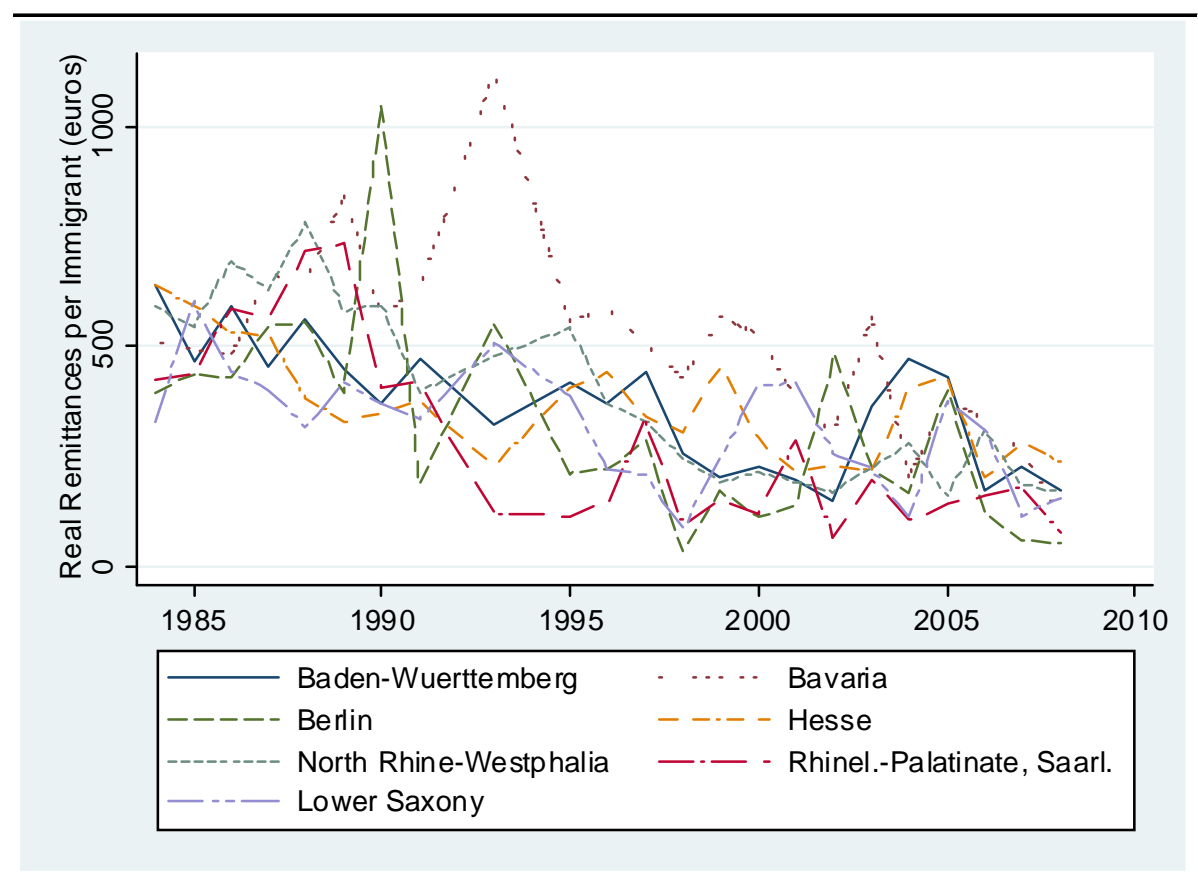

Real remittances per immigrant by West-German state, calculated using individual person weights provided by SOEP. 
FIGURE 5

Remittances per Immigrant by Foreign Country

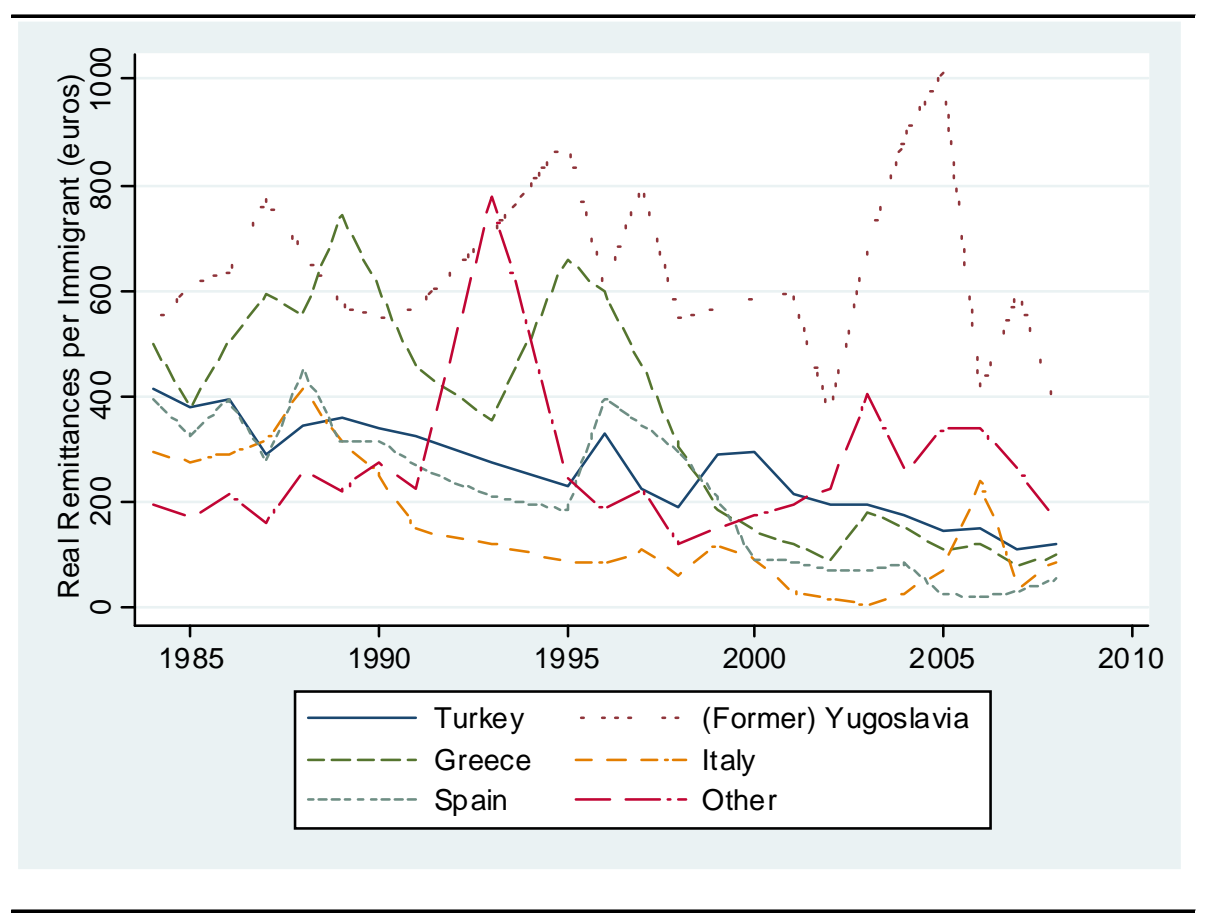

Real remittances per immigrant by foreign country, calculated using individual person weights provided by SOEP. 


\section{FIGURE 6}

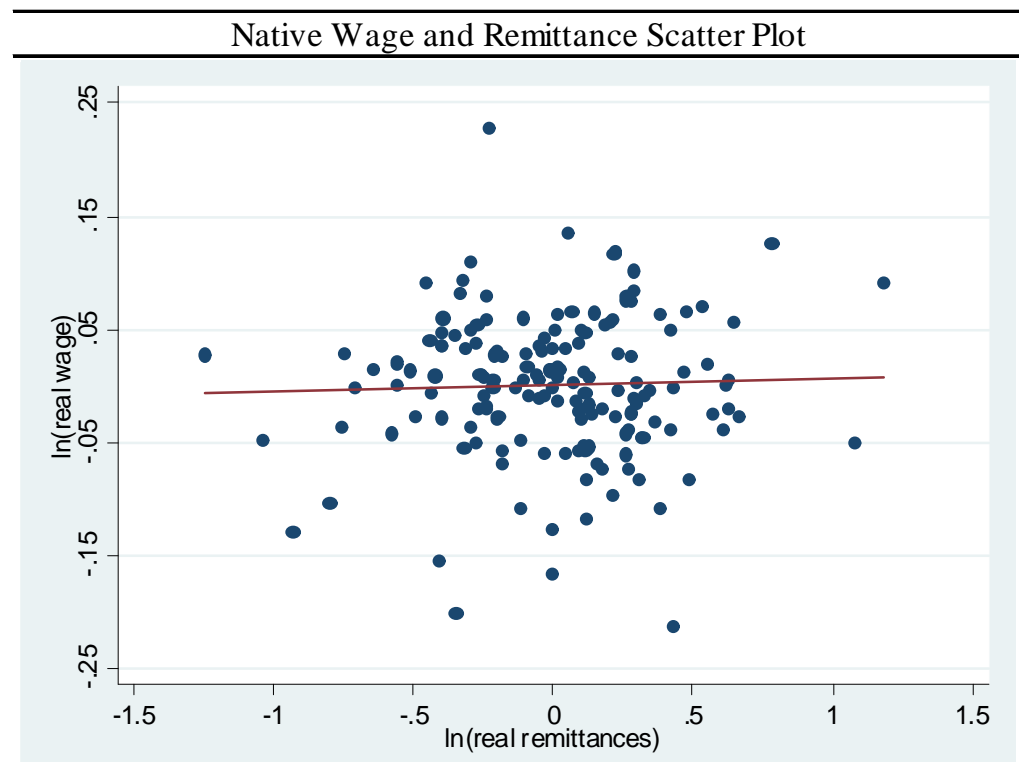

Native Wage and Remittance IV Scatter Plot

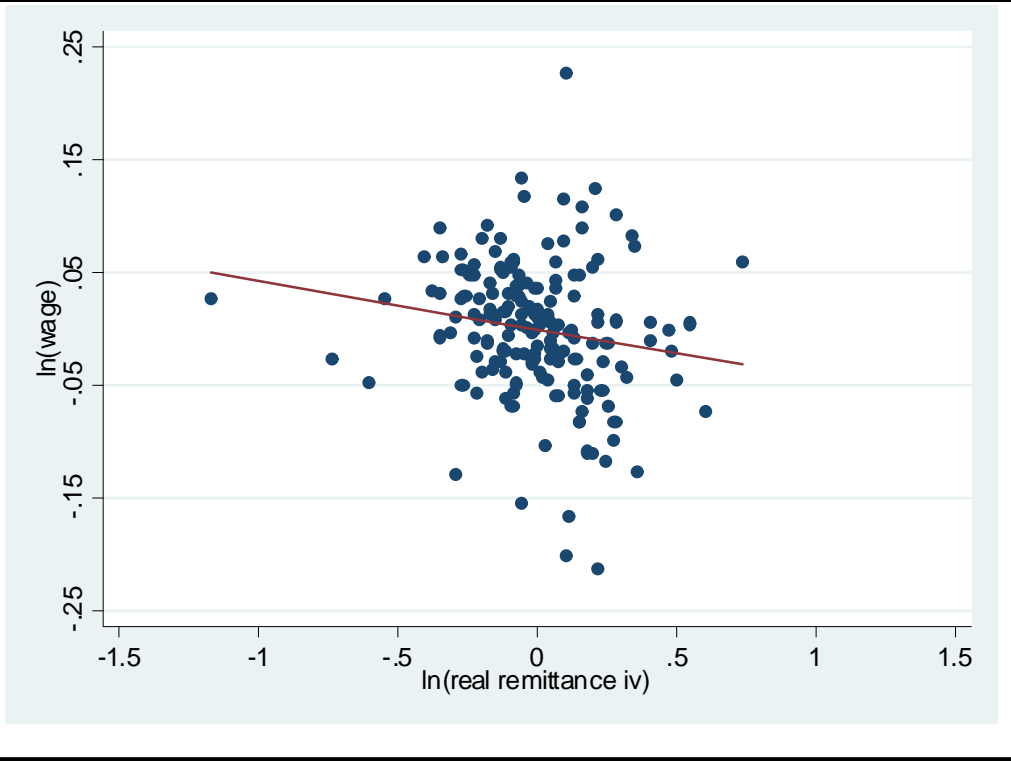

After controlling for state fixed effects and year fixed effects, the average wage of native workers in a German state is plotted against the outflow of real remittances from that state (top panel) and against the remittance instrument (bottom panel). The remittance instrument is constructed using variation in the outflow of remittances that is driven by foreign destination country factors. 
TABLE 1

Summary Statistics of Native Germans

\begin{tabular}{lccccc}
\hline Variable & Obs & Mean & Std. Dev. & Min & Max \\
\hline ln (Wage) & 88,834 & 2.27 & 1.18 & 0 & 7 \\
Education & 88,351 & 12.19 & 2.71 & 7 & 18 \\
Age & 88,834 & 43.97 & 11.93 & 18 & 65 \\
Age Squared & 88,834 & 2076 & 1060 & 324 & 4225 \\
Experience & 88,226 & 18.28 & 12.61 & 0 & 50 \\
Married & 88,834 & 0.61 & 0.49 & 0 & 1 \\
Male & 88,834 & 0.68 & 0.47 & 0 & 1 \\
\hline
\end{tabular}

The native Geramn sample includes 12,853 heads of households spanning 23 years (1984-2008 excluding 1992 and 1994) and 8 West-German states. 
TABLE 2

Impact of Remittances on Native Wages (OLS)

\begin{tabular}{|c|c|c|}
\hline & $\ln$ (Wage) & $\ln$ (Wage) \\
\hline & $(1)$ & (2) \\
\hline \multirow[t]{2}{*}{ In (Remittance) } & $-0.034 * * *$ & $-0.027 * *$ \\
\hline & [0.012] & [0.011] \\
\hline \multirow[t]{2}{*}{ ln (LS Immigrants) } & & -0.028 \\
\hline & & {$[0.033]$} \\
\hline \multirow[t]{2}{*}{ ln (HS Immigrants) } & & $0.095^{* *}$ \\
\hline & & [0.041] \\
\hline \multirow[t]{2}{*}{ Education } & & $0.079 * * *$ \\
\hline & & [0.002] \\
\hline \multirow[t]{2}{*}{ Age } & & $0.102 * * *$ \\
\hline & & {$[0.003]$} \\
\hline \multirow[t]{2}{*}{ Age Squared } & & $-0.001 * * *$ \\
\hline & & [0.000] \\
\hline \multirow[t]{2}{*}{ Experience } & & $0.022 * * *$ \\
\hline & & [0.001] \\
\hline \multirow[t]{2}{*}{ Married } & & $0.045^{* * *}$ \\
\hline & & [0.009] \\
\hline \multirow[t]{2}{*}{ Male } & & $0.140 * * *$ \\
\hline & & [0.010] \\
\hline State FE & Yes & Yes \\
\hline Year FE & Yes & Yes \\
\hline Industry FE & Yes & Yes \\
\hline Observations & 86,436 & 86,012 \\
\hline R-squared & 0.484 & 0.565 \\
\hline
\end{tabular}

Robust standard errors clustered at the state-year level in brackets. $* * * \mathrm{p}<0.01$, ** $\mathrm{p}<0.05, * \mathrm{p}<0.1$. Real remittances, low-skilled immigration, and high-skilled immigration are at the state-year level. Real native wages and all other control variables are at the individual-year level. Regressions weighted by the individual person weights provided by SOEP. 
TABLE 3

First Stage IV Results

\begin{tabular}{|c|c|c|}
\hline & ln (Remittance) & ln (Remittance) \\
\hline & $(1)$ & $(2)$ \\
\hline \multirow[t]{2}{*}{$\ln$ (Remittance IV) } & $0.825^{* * *}$ & $0.834 * * *$ \\
\hline & {$[0.100]$} & {$[0.100]$} \\
\hline \multirow[t]{2}{*}{$\ln$ (LS Immigrants) } & & 0.036 \\
\hline & & {$[0.198]$} \\
\hline \multirow[t]{2}{*}{ ln (HS Immigrants) } & & -0.294 \\
\hline & & {$[0.225]$} \\
\hline \multirow[t]{2}{*}{ Education } & & 0.000 \\
\hline & & {$[0.000]$} \\
\hline \multirow[t]{2}{*}{ Age } & & 0.000 \\
\hline & & {$[0.001]$} \\
\hline \multirow[t]{2}{*}{ Age Squared } & & 0.000 \\
\hline & & {$[0.000]$} \\
\hline \multirow[t]{2}{*}{ Experience } & & 0.000 \\
\hline & & {$[0.000]$} \\
\hline \multirow[t]{2}{*}{ Married } & & 0.000 \\
\hline & & {$[0.002]$} \\
\hline \multirow[t]{2}{*}{ Male } & & 0.000 \\
\hline & & {$[0.002]$} \\
\hline State FE & Yes & Yes \\
\hline Year FE & Yes & Yes \\
\hline Industry FE & Yes & Yes \\
\hline Observations & 86,436 & 86,012 \\
\hline R-squared & 0.895 & 0.896 \\
\hline F-Stat, Instrument & 68.5 & 69.9 \\
\hline
\end{tabular}


TABLE 4

Impact of Remittances on Native Wages (IV)

\begin{tabular}{|c|c|c|}
\hline & $\ln$ (Wage) & ln (Wage) \\
\hline & $(1)$ & $(2)$ \\
\hline \multirow[t]{2}{*}{ ln (Remittance) } & $-0.066 * * *$ & $-0.056 * * *$ \\
\hline & {$[0.022]$} & [0.021] \\
\hline \multirow[t]{2}{*}{ ln (LS Immigrants) } & & -0.014 \\
\hline & & {$[0.034]$} \\
\hline \multirow[t]{2}{*}{ ln (HS Immigrants) } & & $0.088^{* *}$ \\
\hline & & {$[0.041]$} \\
\hline \multirow[t]{2}{*}{ Education } & & $0.079 * * *$ \\
\hline & & [0.002] \\
\hline \multirow[t]{2}{*}{ Age } & & $0.102 * * *$ \\
\hline & & {$[0.003]$} \\
\hline \multirow[t]{2}{*}{ Age Squared } & & $-0.001 * * *$ \\
\hline & & {$[0.000]$} \\
\hline \multirow[t]{2}{*}{ Experience } & & $0.022 * * *$ \\
\hline & & {$[0.001]$} \\
\hline \multirow[t]{2}{*}{ Married } & & $0.045 * * *$ \\
\hline & & [0.009] \\
\hline \multirow[t]{2}{*}{ Male } & & $0.141 * * *$ \\
\hline & & [0.010] \\
\hline State FE & Yes & Yes \\
\hline Year FE & Yes & Yes \\
\hline Industry FE & Yes & Yes \\
\hline Observations & 86,436 & 86,012 \\
\hline R-squared & 0.484 & 0.565 \\
\hline
\end{tabular}

Robust standard errors clustered at the state-year level in brackets. $* * * \mathrm{p}<0.01, * *$ $\mathrm{p}<0.05, * \mathrm{p}<0.1$. Real remittances, low-skilled immigration, and high-skilled immigration are at the state-year level. Real native wages and all other control variables are at the individual-year level. Regressions weighted by the individual pers on weights provided by SOEP. 
TABLE 5

Impact of Remittances on Native Wages by Traded and Non-Traded Industries

\begin{tabular}{|c|c|c|c|c|}
\hline & \multicolumn{2}{|c|}{ OLS } & \multicolumn{2}{|c|}{ IV } \\
\hline & Traded & Non-Traded & Traded & Non-Traded \\
\hline & (1) & (2) & (3) & (4) \\
\hline \multirow[t]{2}{*}{ ln (Remittance) } & -0.013 & $-0.034 * *$ & $-0.051 * * *$ & $-0.058 * *$ \\
\hline & {$[0.010]$} & {$[0.015]$} & {$[0.018]$} & [0.029] \\
\hline \multirow[t]{2}{*}{ ln (LS Immigrants) } & 0.018 & -0.048 & 0.038 & -0.037 \\
\hline & [0.029] & {$[0.048]$} & [0.030] & {$[0.048]$} \\
\hline \multirow[t]{2}{*}{ In (HS Immigrants) } & 0.053 & $0.108 * *$ & 0.042 & $0.103^{*}$ \\
\hline & [0.039] & [0.053] & {$[0.040]$} & [0.053] \\
\hline \multirow[t]{2}{*}{ Education } & $0.068 * * *$ & $0.082 * * *$ & $0.068 * * *$ & $0.082 * * *$ \\
\hline & [0.002] & [0.002] & [0.002] & [0.002] \\
\hline \multirow[t]{2}{*}{ Age } & $0.059 * * *$ & $0.116 * * *$ & $0.059 * * *$ & $0.117 * * *$ \\
\hline & [0.004] & [0.004] & [0.004] & [0.004] \\
\hline \multirow[t]{2}{*}{ Age Squared } & $-0.001 * * *$ & $-0.002 * * *$ & $-0.001 * * *$ & $-0.002 * * *$ \\
\hline & {$[0.000]$} & {$[0.000]$} & [0.000] & [0.000] \\
\hline \multirow[t]{2}{*}{ Experience } & $0.013 * * *$ & $0.023 * * *$ & $0.013 * * *$ & $0.023 * * *$ \\
\hline & [0.001] & {$[0.001]$} & {$[0.001]$} & [0.001] \\
\hline \multirow[t]{2}{*}{ Married } & $0.053 * * *$ & $0.045^{* * *} *$ & $0.053 * * *$ & $0.045 * * *$ \\
\hline & [0.008] & [0.013] & {$[0.008]$} & [0.013] \\
\hline \multirow[t]{2}{*}{ Male } & $0.131 * * *$ & $0.156^{* * *}$ & $0.131 * * *$ & $0.156^{* * *}$ \\
\hline & [0.011] & {$[0.014]$} & [0.011] & [0.014] \\
\hline State FE & Yes & Yes & Yes & Yes \\
\hline Year FE & Yes & Yes & Yes & Yes \\
\hline Industry FE & Yes & Yes & Yes & Yes \\
\hline Observations & 31,216 & 54,796 & 31,216 & 54,796 \\
\hline R-squared & 0.249 & 0.561 & 0.249 & 0.561 \\
\hline
\end{tabular}

Robust standard errors clustered at the state-year level in brackets. $* * * \mathrm{p}<0.01, * * \mathrm{p}<0.05,{ }^{*} \mathrm{p}<0.1$. Traded industries include Agriculture, Trade, Mining, Transport, Manufacturing, Energy, and Finance. Non-Traded industries include Services, Construction, and Other. Regressions weighted by the individual person weights provided by SOEP. 
TABLE 6

Impact of Post-1990 Remittances on Output (IV)

\begin{tabular}{lccc}
\hline & Total & Traded Industries & Non-Traded Industries \\
\hline & $(1)$ & $(2)$ & $(3)$ \\
\hline \multirow{2}{*}{ (nemittance) } & & & $-0.025^{* * *}$ \\
& $-0.019^{* *}$ & $-0.016^{*}$ & {$[0.008]$} \\
$\ln$ (LS Immigrants) & {$[0.009]$} & {$[0.010]$} & -0.017 \\
& -0.027 & -0.029 & {$[0.015]$} \\
$\ln$ (HS Immigrants) & {$[0.018]$} & {$[0.020]$} & $0.128^{* * *}$ \\
& $0.140^{* * *}$ & $0.142^{* * *}$ & {$[0.022]$} \\
State FE & {$[0.027]$} & {$[0.029]$} & Yes \\
Year FE & Yes & Yes & Yes \\
& Yes & Yes & 112 \\
Observations & & & 0.998 \\
R-squared & 112 & 112 & 0.998 \\
\hline Rebust stan
\end{tabular}

Robust standard errors in brackets. $* * * \mathrm{p}<0.01, * * \mathrm{p}<0.05, * \mathrm{p}<0.1$. The dependent variable is output, measured as value added, at the state-year level. Real remittances, low-skilled immigration, and highskilled immigration are at the state-year level. Traded industries include Agriculture, Trade, Mining, Transport, Manufacturing, Energy, and Finance. Non-Traded industries include Services and Construction. 
TABLE 7

Impact of Remittances on Native Wages by Union and Non-Union Industries

\begin{tabular}{|c|c|c|c|c|}
\hline & \multicolumn{2}{|c|}{ OLS } & \multicolumn{2}{|c|}{ IV } \\
\hline & Union & Non-Union & Union & Non-Union \\
\hline & $(1)$ & (2) & (3) & (4) \\
\hline \multirow[t]{2}{*}{ ln (Remittance) } & 0.000 & $-0.041 * * *$ & -0.033 & $-0.064^{* *}$ \\
\hline & {$[0.010]$} & [0.015] & {$[0.020]$} & {$[0.026]$} \\
\hline \multirow[t]{2}{*}{ ln (LS Immigrants) } & 0.002 & -0.034 & 0.020 & -0.023 \\
\hline & {$[0.030]$} & {$[0.042]$} & {$[0.033]$} & {$[0.042]$} \\
\hline \multirow[t]{2}{*}{ ln (HS Immigrants) } & 0.027 & $0.109^{* *}$ & 0.016 & $0.105^{* *}$ \\
\hline & {$[0.036]$} & {$[0.053]$} & {$[0.037]$} & {$[0.052]$} \\
\hline \multirow[t]{2}{*}{ Education } & $0.073 * * *$ & $0.078 * * *$ & $0.073 * * *$ & $0.078 * * *$ \\
\hline & [0.002] & [0.002] & [0.002] & [0.002] \\
\hline \multirow[t]{2}{*}{ Age } & $0.053 * * *$ & $0.117 * * *$ & $0.053 * * *$ & $0.117 * * *$ \\
\hline & [0.003] & [0.004] & [0.003] & [0.004] \\
\hline \multirow[t]{2}{*}{ Age Squared } & $-0.001 * * *$ & $-0.002 * * *$ & $-0.001 * * *$ & $-0.002 * * *$ \\
\hline & [0.000] & [0.000] & [0.000] & [0.000] \\
\hline \multirow[t]{2}{*}{ Experience } & $0.011 * * *$ & $0.023 * * *$ & $0.011 * * *$ & $0.023 * * *$ \\
\hline & [0.001] & [0.001] & [0.001] & [0.001] \\
\hline \multirow[t]{2}{*}{ Married } & $0.067 * * *$ & $0.042 * * *$ & $0.067 * * *$ & $0.042 * * *$ \\
\hline & [0.009] & {$[0.012]$} & [0.009] & [0.012] \\
\hline \multirow[t]{2}{*}{ Male } & $0.124 * * *$ & $0.150 * * *$ & $0.124 * * *$ & $0.150 * * *$ \\
\hline & [0.013] & {$[0.012]$} & [0.013] & [0.012] \\
\hline State FE & Yes & Yes & Yes & Yes \\
\hline Year FE & Yes & Yes & Yes & Yes \\
\hline Industry FE & Yes & Yes & Yes & Yes \\
\hline Observations & 28,741 & 57,271 & 28,741 & 57,271 \\
\hline R-squared & 0.182 & 0.543 & 0.182 & 0.543 \\
\hline
\end{tabular}

Robust standard errors clustered at the state-year level in brackets. *** $\mathrm{p}<0.01,{ }^{*} \mathrm{p}<0.05,{ }^{*} \mathrm{p}<0.1$. Unionized industries include Mining, Energy, Transport, Manufacturing, and Construction. Non-unionized industries include Agriculture, Trade, Finance, Services, and Other. Regressions weighted by the individual person weights provided by SOEP. 
TABLE 8

Impact of Pre-1996 Remittance Components on Native Wages

\begin{tabular}{|c|c|c|c|c|}
\hline & \multicolumn{2}{|c|}{ OLS } & \multicolumn{2}{|c|}{ IV } \\
\hline & Family & Savings & Family & Savings \\
\hline & $(1)$ & $(2)$ & (3) & (4) \\
\hline ln (Remittance - Family) & $\begin{array}{c}-0.066 * * * \\
{[0.019]}\end{array}$ & & $\begin{array}{c}-0.110 * * * \\
{[0.028]}\end{array}$ & \\
\hline ln (Remittance - Savings) & & $\begin{array}{l}-0.013 \\
{[0.009]}\end{array}$ & & $\begin{array}{c}0.742 \\
{[2.191]}\end{array}$ \\
\hline ln (LS Immigrants) & $\begin{array}{c}0.200 * * \\
{[0.081]}\end{array}$ & $\begin{array}{l}0.146^{*} \\
{[0.076]}\end{array}$ & $\begin{array}{c}0.255^{* * * *} \\
{[0.086]}\end{array}$ & $\begin{array}{c}0.195 \\
{[0.730]}\end{array}$ \\
\hline ln (HS Immigrants) & $\begin{array}{c}-0.100 \\
{[0.067]}\end{array}$ & $\begin{array}{c}-0.027 \\
{[0.068]}\end{array}$ & $\begin{array}{c}-0.135^{*} \\
{[0.079]}\end{array}$ & $\begin{array}{c}0.110 \\
{[0.852]}\end{array}$ \\
\hline Education & $\begin{array}{c}0.078^{* * *} * \\
{[0.003]}\end{array}$ & $\begin{array}{c}0.078^{* * *} \\
{[0.003]}\end{array}$ & $\begin{array}{c}0.078^{* * * *} \\
{[0.003]}\end{array}$ & $\begin{array}{c}0.078 * * * \\
{[0.003]}\end{array}$ \\
\hline Age & $\begin{array}{c}0.094 * * * \\
{[0.005]}\end{array}$ & $\begin{array}{c}0.095^{* * *} \\
{[0.005]}\end{array}$ & $\begin{array}{c}0.094 * * * \\
{[0.005]}\end{array}$ & $\begin{array}{c}0.096^{* * * *} \\
{[0.006]}\end{array}$ \\
\hline Age Squared & $\begin{array}{c}-0.001 * * * \\
{[0.000]}\end{array}$ & $\begin{array}{c}-0.001 * * * \\
{[0.000]}\end{array}$ & $\begin{array}{c}-0.001 * * * \\
{[0.000]}\end{array}$ & $\begin{array}{c}-0.001 * * * \\
{[0.000]}\end{array}$ \\
\hline Experience & $\begin{array}{c}0.023^{* * *} * \\
{[0.001]}\end{array}$ & $\begin{array}{c}0.023^{* * *} * \\
{[0.001]}\end{array}$ & $\begin{array}{c}0.023^{* * *} * \\
{[0.001]}\end{array}$ & $\begin{array}{c}0.023^{* * *} * \\
{[0.001]}\end{array}$ \\
\hline Married & $\begin{array}{c}0.092 * * * \\
{[0.016]}\end{array}$ & $\begin{array}{c}0.097 * * * \\
{[0.016]}\end{array}$ & $\begin{array}{c}0.091 * * * \\
{[0.016]}\end{array}$ & $\begin{array}{c}0.102 * * * \\
{[0.020]}\end{array}$ \\
\hline Male & $\begin{array}{c}0.115^{* * *} * \\
{[0.019]}\end{array}$ & $\begin{array}{c}0.111 * * * \\
{[0.019]}\end{array}$ & $\begin{array}{c}0.115^{* * * *} \\
{[0.019]}\end{array}$ & $\begin{array}{c}0.111 * * * \\
{[0.019]}\end{array}$ \\
\hline State FE & Yes & Yes & Yes & Yes \\
\hline Year FE & Yes & Yes & Yes & Yes \\
\hline Industry FE & Yes & Yes & Yes & Yes \\
\hline $\begin{array}{l}\text { Observations } \\
\text { R-squared }\end{array}$ & $\begin{array}{c}26,691 \\
0.577 \\
\end{array}$ & $\begin{array}{c}26,115 \\
0.576 \\
\end{array}$ & $\begin{array}{c}26,691 \\
0.577 \\
\end{array}$ & $\begin{array}{c}26,115 \\
0.453 \\
\end{array}$ \\
\hline
\end{tabular}

Robust standard errors clustered at the state-year level in brackets. *** $\mathrm{p}<0.01, * * \mathrm{p}<0.05$, $* \mathrm{p}<0.1$. Remittance components only available pre-1996. Real remittances and immigration are at the state-year level. Real native wages and all other control variables are at the individual-year level. Regressions weighted by the individual person weights provided by SOEP. 
TABLE 9

Impact of Remittances on Native Wages - Sensitivity Analysis (IV)

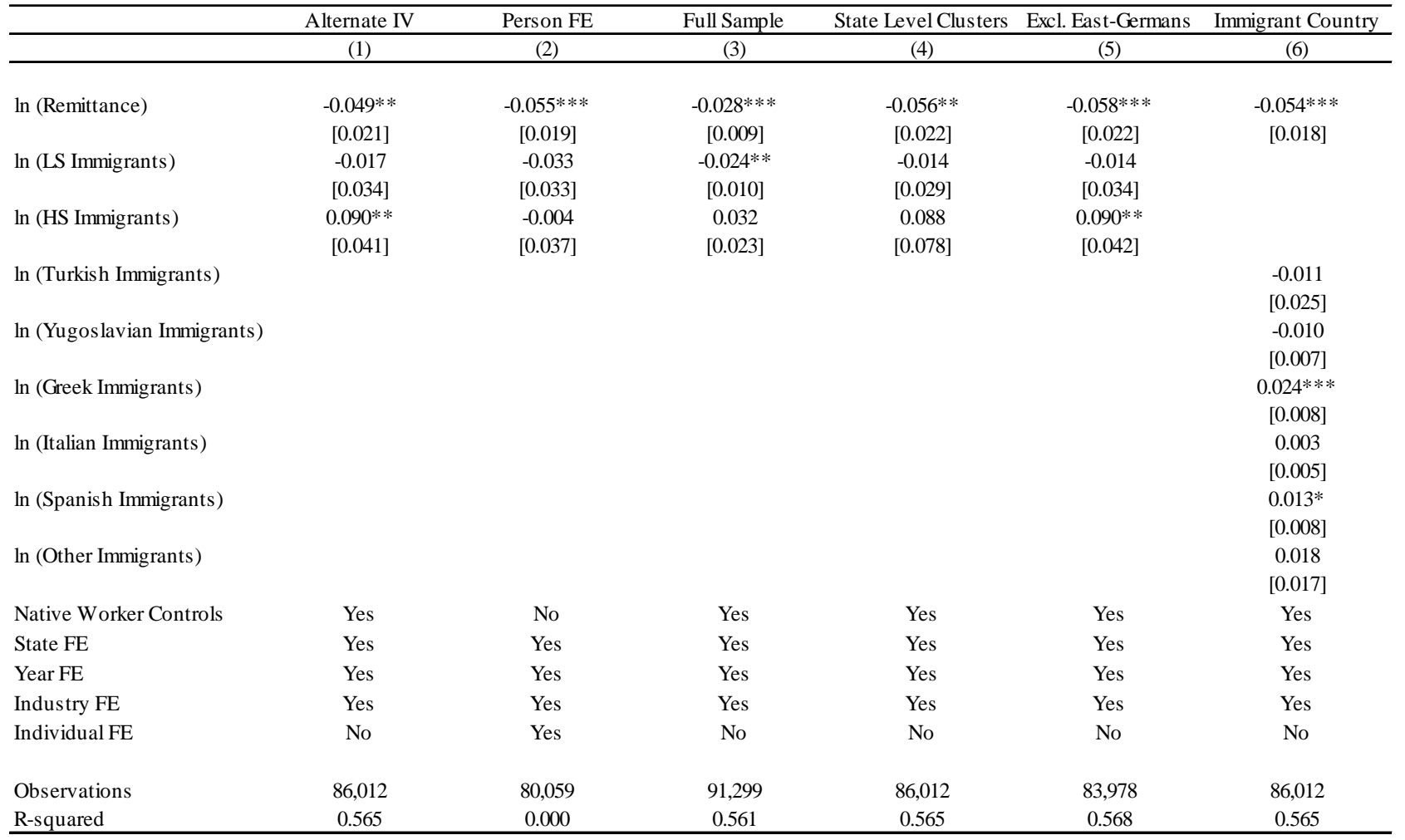

Robust standard errors clustered at the state-year level in brackets in columns $1-6 . * * * \mathrm{p}<0.01, * * \mathrm{p}<0.05$, * $\mathrm{p}<0.1$. The alternate IV in column 1 is

constructed by regressing immigrant remittances on individual controls, state*year FE, country*year FE, industry*year FE, and keeping the country*year

FE to construct the instrument. Column 2 includes individual person fixed effects. The sample in column 3 includes all West-German states including

Schleswig-Holstein, Hamburg, and Bremen which have limited remittance data. The standard errors are clustered at the state level in column 4 . Column 5

excludes the subsample of East-Germans who live in West-German states. Finally, column 6 controls for the country of origin of the immigrant rather than immigrant skill level. 


\section{A Appendix}

It is also possible to examine the impact of immigration on wages in the long-run where the price of capital is fixed but the capital stock can change. Taking the natural log of equations (7) and (8) gives:

$$
\ln w=\ln (1-\alpha)+\eta \ln C+(1-\eta)[\alpha \ln K+(1-\alpha) \ln L]-\ln L
$$

and

$$
\ln r=\ln (\alpha)+\eta(\ln C)+(1-\eta)[\alpha \ln K+(1-\alpha) \ln L]-\ln K
$$

Rearranging the latter equation and differentiating leads to the following immigrationinduced change in the capital stock (where it is assumed that in the long-run $d r=0$ ):

$$
\frac{d \ln K}{d \ln L}=\frac{\eta \phi+(1-\eta)(1-\alpha)}{1-(1-\eta) \alpha}>0
$$

Not surprisingly, this term is positive which indicates that as the workforce increases due to immigration, the capital stock will increase as well. With product market neutrality $(\phi=1)$, this equation equals one which indicates that the capital stock will grow at the same rate as the immigration-induced change in labor supply.

Differentiating the $\ln w$ equation, using the immigration-induced change in the capital stock equation, generates the following long-run relationship between immigration and wages:

$$
\frac{d \ln w}{d \ln L}=\eta \phi+(1-\eta) \alpha\left[\frac{\eta \phi+(1-\eta)(1-\alpha)}{1-(1-\eta) \alpha}\right]+(1-\eta)(1-\alpha)-1
$$

or

$$
\frac{d \ln w}{d \ln L}=\frac{\eta(\phi-1)}{1-(1-\eta) \alpha}
$$

With product market neutrality $(\phi=1)$, this model generates the standard result that immigration has no impact on wages in the long-run. The capital stock increases by the same proportion as the immigration-induced increase in the workforce which leaves the capital to labor ratio constant and thus wages do not change. However, if $\phi>1$, then immigration has a positive impact on wages in the long-run and if $\phi<1$, then immigration has a negative impact on wages in the long-run. 